\title{
Remittances, Migrants' Education and Immigration Policy: Theory and Evidence from Bilateral Data*
}

\author{
Frédéric Docquier ${ }^{a}$, Hillel Rapoport ${ }^{b}$ and Sara Salomone ${ }^{c}$ \\ ${ }^{a}$ IRES, Université Catholique de Louvain, and FNRS \\ ${ }^{b}$ Department of Economics, Bar-Ilan University, EQUIPPE, University of Lille, and \\ Center for International Development, Harvard University \\ ${ }^{c}$ IRES, Université Catholique de Louvain, and Tor Vergata University
}

October 2011

\begin{abstract}
We investigate the relationship between remittances and migrants' education both theoretically and empirically, using original bilateral remittance data. At a theoretical level we lay out a model of remittances interacting migrants' human capital with two dimensions of immigration policy: restrictiveness, and selectivity. The model predicts that the relationship between remittances and migrants' education is ambiguous and depends on the immigration policy conducted at destination. The effect of education is more likely to be positive when the immigration policy is more restrictive and less skill-selective. These predictions are then tested empirically using bilateral remittance and migration data and proxy measures for the restrictiveness and selectivity of immigration policies at destination. The results strongly support the theoretical analysis, suggesting that immigration policies determine the sign and magnitude of the relationship between remittances and migrants' education.

Keywords: Remittances, Migration, Brain Drain, Immigration Policy. JEL codes: F24, F22, O15, J61.
\end{abstract}

*This research was jointly supported by the Agence Française de Développement (AFD) and the World Bank (Development Research Group). We are grateful to Leonardo Becchetti, Michel Beine, Giuseppe de Arcangelis, Yves Zenou and an anonymous referee for useful comments. We also thank the scholars and organizations who graciously allowed us to use their bilateral remittances data, and participants at the Third Migration and Development conference held at the Paris School of Economics in September 2010 for comments and suggestions. Frédéric Docquier and Sara Salomone acknowledge financial support from the ARC convention on "Geographical Mobility of Factors" (convention 09/14-019). Correspondence: Frédéric Docquier (frederic.docquier@uclouvain.be), Hillel Rapoport (hillel@mail.biu.ac.il) and Sara Salomone (sara.salomone@uclouvain.be). 


\section{Introduction}

This paper investigates the relationship between remittances and migrants' education both theoretically and empirically, using original bilateral remittances data. This question is important because the increasingly quality-selective nature of immigration policies in many traditional destinations (favoring immigration of highly educated workers and at the same time discouraging immigration of low-skill workers) has raised concerns in developing countries and among international development agencies that such policy changes will result in more brain drain and less remittances. These concerns are based on the tacit view that the highly educated remit less. And indeed, there are many reasons to expect a negative relationship between remittances and migrants' education: more educated migrants often come from richer families and have a higher propensity to migrate with their entire household (hence, less need to send remittances) and a lower propensity to return, reducing the incentives to remit as a way of maintaining prestige and ties to the home community. On the other hand, better educated migrants have a higher income potential, are less likely to be illegal and more likely to have bank accounts and access to less costly transfer means. In addition, their education may have been funded by informal loans from family members to be repaid with interest in the form of remittances. ${ }^{1}$ A priori then, it is not clear theoretically whether the highly skilled will remit more or less on average. Empirically, the question has been surprisingly understudied.

At a macro level, the only empirical evidence to look at this issue using aggregate data are two recent papers by Faini (2007) and Niimi, Ozden and Schiff (2010). Faini (2007) shows that migrants' remittances decrease with the proportion of skilled individuals among emigrants and concludes: "this result suggests that the negative impact of the brain drain cannot be counterbalanced by higher remittances". However, any correlation between remittances and the skill level observed across countries may be spurious. ${ }^{2}$ To account for endogeneity issues, Niimi, Ozden and Schiff (2010) instrument the number of emigrants (but treat the proportion of skilled as exogenous) and obtain similar qualitative results. The macro literature also includes one bilateral study by Schioupu and Siegfried (2006) who used a bilateral remittances database recently released by the European Central Bank and found instead a negative correlation between the share of low-skill workers and remittance receipts, suggesting that in contrast to the results obtained with aggregate data, migrants' skills tend to raise remittances. ${ }^{3}$

\footnotetext{
${ }^{1}$ See Rapoport and Docquier (2006) for a comprehensive survey of the literature on migrants' remittances. See also Ashraf et al. (2010) for experimental evidence on financial education and remittances.

${ }^{2}$ For example, if poverty is a constraint to both migration and education, we may find richer developing countries being able to send more migrants (yielding more remittances), and that these migrants also have more schooling.

${ }^{3}$ Other recent studies of the determinants of remittances using bilateral data include Lueth and Ruiz-Arranz (2008), de Sousa and Duval (2010), and Frankel (2011). However these studies do not
} 
At a micro level, Bollard et al. (2011) examine the relationship between remittances and migrants' education using household survey data on immigrants in eleven destination countries. They find a mixed pattern between higher education and the likelihood of remitting, and a strong positive relationship between higher education and the amount remitted conditional on remitting. Combining these intensive and extensive margins gives an overall positive effect of higher education on the amount remitted, with an expected amount of $\$ 1,000$ annually for a migrant with a university degree against $\$ 750$ for someone without university degree. In relative terms however, and for the surveys containing information on income, the less educated tend to remit a larger share of their income. Bollard et al. (2011) also investigate why the more educated remit more and find the higher income earned by migrants, rather than characteristics of their family situations or their return intentions, explains much of the higher remittances. It is noteworthy that these results are obtained for the pooled data and hold for most but not all surveys; for example, they are not supported in the case of immigrants surveyed as part of the German Socio-Economic Panel, for which there is a negative (but not significant) association between remittances and holding a university degree. And indeed, using different waves of the German SocioEconomic Panel, Dustmann and Mestres (2010) find a negative effect of education on remittances after controlling for intentions to return and household composition at destination. Duval and Wolff (2011) also use longitudinal survey data on remittances to Albania and find remittances decrease with both the migrants and recipients' level of education.

This paper makes three contributions in terms of data, theory, and empirics. The first contribution is to build in Section 3 a new bilateral remittances database by merging various sources to capture bilateral remittances from 89 sending to 46 receiving countries over the period 1985-2005. To the best of our knowledge, the resulting database is the most comprehensive bilateral remittance data set currently available. Second, we lay out in Section 2 a simple model of remittance behavior interacting migrants' human capital with two dimensions of immigration policies: restrictiveness, and selectivity. Our model predicts that the microeconomic relationship between the amount remitted and the migrant's skill level is inverse-U shaped, with the increasing segment being longer (resp. shorter) for more restrictive (resp. selective) immigration policies. The main testable implication, therefore, is that for a given country pair, a more skilled pool of migrants will send more (resp. less) remittances if the destination country has a more restrictive (resp. selective) immigration policy. Finally, these predictions are tested in Section 4 using bilateral remittance data and proxy measures for the restrictiveness and selectivity of immigration policies at destination.

look at the effect of the skill composition of bilateral migration flows. 


\section{Theoretical foundations}

In this section, we study the microfoundations of the relationship between aggregate remittances and the skill composition of migration. We show that the sign and intensity of the relationship depend on the type of immigration policies in the destination countries.

Our model starts from a tautological decomposition of bilateral remittances into two additive components: remittances sent by highly skilled migrants (with human capital $h^{s}$ ) and remittances sent by low skilled migrants (with human capital $h^{u}$ ). The aggregate amount of bilateral remittances sent by migrants born in country $i$ (the recipient country) and living in country $j$ (the transferring country) at time $t$ $\left(R_{i j t}\right)$ can be expressed as:

$$
R_{i j t}=M_{i j t}^{s} T_{i j t}^{s}+M_{i j t}^{u} T_{i j t}^{u}
$$

where $M_{i j t}^{k}$ stands for the bilateral migration stock of type- $k$ migrants ( $k$ equals $s$ for high-skilled, $u$ for low-skilled, and $s+u$ for total), and $T_{i j t}^{k}$ represents the amount remitted per migrant.

To emphasize the effect of the skill composition of migration on remittances, the above equation can be rewritten as

$$
R_{i j t}=M_{i j t}^{s+u} T_{i j t}^{u}\left(1+\frac{M_{i j t}^{s}}{M_{i j t}^{s+u}} \frac{T_{i j t}^{s}-T_{i j t}^{u}}{T_{i j t}^{u}}\right)
$$

Defining $\sigma_{i j t} \equiv M_{i j t}^{s} / M_{i j t}^{s+u}$ as the proportion of highly skilled in the bilateral migration stock from $i$ to $j, \Delta_{i j t} \equiv\left(T_{i j t}^{s}-T_{i j t}^{u}\right) / T_{i j t}^{u}$ as the excess amount remitted by a highly skilled individual relatively to a low skilled one (which can be positive or negative), taking logs, and considering a linear approximation given that $\sigma_{i j t} \Delta_{i j t}$ (the product of two proportions) is not too large, we have:

$$
\ln R_{i j t}=\ln M_{i j t}^{s+u}+\ln T_{i j t}^{u}+\sigma_{i j t} \Delta_{i j t}
$$

If highly skilled migrants remit more than low-skilled migrants $\left(\Delta_{i j t}>0\right)$, then the aggregate amount of remittances should increase with migrants' education level. If they remit less $\left(\Delta_{i j t}<0\right)$, then the aggregate amount of remittances decreases with migrants' education level.

Equation (1) can therefore serve as a basis for our empirical analysis. Our point is that $\Delta_{i j t}$ needs not be homogeneous across destinations. In particular, its sign and magnitude depend on the immigration policies conducted in destination countries. To illustrate this, we endogenize $\Delta_{i j t}$ in the next section.

\subsection{Determinants of $\Delta_{i j t}$}

To understand the determinants of $\Delta_{i j t}$, we study the microfoundations of the remittance behavior and endogenize the amount $T_{i j t}^{k}$ sent by each migrant. Although the 
data only enable us to distinguish two groups of migrants, we first abstract from the bilateral structure of migration (for simplicity, subscripts $i, j$ and $t$ are omitted in this section) and study the link between a migrant's skill level $h \geq 1$ and the amount transferred. ${ }^{4}$ The skill price in the destination country is denoted by $w^{*}$ whereas the skill price at origin is denoted by $w<w^{*}$. Both are treated as exogenous.

Before we proceed with the model it is important to empasize that the model below can receive two interpretations that cover the two main motivations to remit emphasized in the literature: altruism and exchange. The first of these motives is more static in nature as it primarily aims at redistributing income among the members of a given family at a given point in time. The second motive is in essence more dynamic as remittances motivated by exchange generally aim at maintaining or developing the migrant's capital at home (be it social or physical) and prepare his return at a later period. From that second perspective, the model can therefore be viewed as a dynamic model in which the migrants live for two periods: they migrate in the first period and decide which fraction of time $\theta$ to spend abroad in the second period. The amount remitted $T$ is then equivalent to accumulating savings (at unitary return rate) in order to prepare one's return to the home country. This second interpretation, therefore, treats remittances as savings resulting from an individual intertemporal choice. Alternatively, the model can also be interpreted as a static model in which the migrants care about their own utility and the utility of other family members, a fraction $\theta$ of whom can be brought with the migrant as dependents. For simplicity, in the static case, we normalize family size (excluding the migrant) to unity and assume that transfers are such that all family members' incomes (including the migrant and those who stay in the home country) are equalized.

Immigration policies at destination are assumed to be fully characterized by two parameters. A first scale parameter, denoted by $c$, captures the "restrictiveness" of immigration policy: the higher $c$, the higher the cost of increasing the fraction of time $\theta$ (e.g., through obtaining a permanent visa) during which the migrant is able to stay at destination during the second period; or, in the static model, the higher the cost of bringing additional family members through family reunion programs. A second parameter, denoted by a, captures the "selectivity" of immigration policy: the higher $a$, the larger the cost advantage for an educated migrant to extend her stay during the second period or to bring additional family members. Formally, for a migrant of type $h$, the utility cost of staying a proportion $\theta$ of the second period (in the dynamic model) or to attract $\theta$ percent of the family (in the static one) may be written as:

$$
C(\theta ; h)=\frac{c \theta}{h^{a}}
$$

The migrant's utility is assumed to be logarithmic in income and must account for the cost of an extended stay or of bringing additional family members. It can be

\footnotetext{
${ }^{4}$ The assumption that $h \geq 1$ is reasonably always satisfied if $h$ measures, for example, the number of years of schooling or the number of efficiency units of labor.
} 
written as:

$$
U(T, \theta ; h)=\ln \left[w^{*} h-T\right]+\ln \left[\theta w^{*} h+(1-\theta) w h+T\right]-\frac{c \theta}{h^{a}}
$$

where the utility cost of $\theta$ is substracted as an effort or time cost for mathematical tractability.

The utility function must be maximized with respect to $T$ and $\theta$. To highlight the determinants of remittances, we solve the optimization problem in two steps. We first derive the optimal amount of transfer for a given migration type (i.e., for a given $\theta$ ). Then we solve the selection issue and plug the optimal level of $\theta$ into the remittance equation. This procedure enables us to disentangle the direct and indirect impacts of migrants' education on remittances. Another advantage is that it simplifies the characterization of corner regimes. However, it is worth noticing that a one-step procedure (i.e., solving a system of two first-order conditions) would generate exactly the same results.

Maximizing (3) with respect to $T$ gives:

$$
T^{*}(\theta ; h)=\frac{(1-\theta)\left(w^{*}-w\right) h}{2}
$$

Clearly, there will be no remittances if $\theta=1$, that is, if migration is permanent (in the dynamic interpretation of the model) or if the migrant brings with her all the members of the family (in the static model). For any given $\theta<1$, the amount remitted is always positive given that $w^{*}>w$ and is proportional to the migrant's skill level $h$. Micro-level empirical studies, therefore, should find a positive effect of migrants' skills on remittances after controlling for the location of the family members and for the expected duration of stay at destination (see Bollard et al., 2011). Such control variables, however, are not available at the macro level. Besides, the unobserved propensity to extend one's stay or to bring family members might be endogenous and vary with the migrants' human capital.

Substituting $T^{*}$ into the utility function (3) gives the following quasi-indirect utility function:

$$
V(\theta ; h)=2 \ln \left[\frac{(1+\theta) w^{*} h+(1-\theta) w h}{2}\right]-\frac{c \theta}{h^{a}}
$$

Maximizing $V(\theta ; h)$ with respect to $\theta$ gives

$$
\theta^{*}(h)=\left\{\begin{array}{l}
0 \text { if } h \leq h_{0} \\
\frac{2\left(w^{*}-w\right) h^{a}-c\left(w^{*}+w\right)}{c\left(w^{*}-w\right)} \quad \text { if } h \in\left[h_{0}, h_{1}\right] \\
1 \text { if } h \geq h_{1}
\end{array}\right.
$$


The interior solution is obtained by setting $V^{\prime}=0$. Since $V^{\prime \prime}<0$, it is a maximum. A corner solution is obtained when $h \notin\left[h_{0}, h_{1}\right]$. The critical levels of human capital $h_{0} \equiv\left[\frac{c\left(w^{*}+w\right)}{2\left(w^{*}-w\right)}\right]^{1 / a}$ and $h_{1} \equiv\left[\frac{c w^{*}}{w^{*}-w}\right]^{1 / a}$ are such that $h_{1}>h_{0}$; they are increasing with the restrictiveness of the immigration policy $(c)$ and are decreasing with the intensity of skill-selective programs $(a)$. If human capital is very low $\left(h \leq h_{0}\right)$, migrants will choose to move alone and will be unable to extend their stay beyond the first period $\left(\theta^{*}=0\right)$. This situation is likely to be observed in destination countries conducting guest worker programs (e.g., in the member countries of the Gulf Cooperation Council) where $c$ is very high. If human capital is very high $\left(h \geq h_{1}\right)$, migrants will choose to bring all their family members with them or move permanently $\left(\theta^{*}=1\right)$.

Focusing on the interior solution, the time spent abroad, or the number of sponsored relatives (i.e. $\theta^{*}(h)$ ), increases with the migrant's human capital when the destination country conducts a selective policy $(a>0)$ and decrease with the restrictiveness of the immigration policy $(c)$. Note that $\theta^{*}(h)$ is an increasing and concave function of $h$ if skill-selection is weak $(a<1)$ and an increasing and convex function of $h$ if skill-selection is strong $(a>1)$. In both cases, highly skilled migrants are richer but migrate for longer periods or with more family members. The amount remitted then becomes an ambiguous function of migrant's education. Substituting $\theta^{*}(h)$ from (6) into (4) gives the reduced-form expression for the optimal amount of remittances:

$$
T^{*}(h)=\left\{\begin{array}{l}
T_{0}(h) \equiv\left(w^{*}-w\right) \frac{h}{2} \quad \text { if } h \leq h_{0} \\
T(h) \equiv\left[c w^{*}-\left(w^{*}-w\right) h^{a}\right] \frac{h}{c} \text { if } h \in\left[h_{0}, h_{1}\right] \\
T_{1}(h) \equiv 0 \text { if } h \geq h_{1}
\end{array}\right.
$$

The function $T_{0}(h)$ is linear and increasing in $h$. The function $T(h)$ is concave in $h$, such that $T(0)=T\left(h_{1}\right)=0$. It reaches a maximum at $h_{m}$ defined as

$$
h_{m}=\left[\frac{c w^{*}}{(1+a)\left(w^{*}-w\right)}\right]^{1 / a}
$$

which is higher than $h_{0}$ if and only if $a<\frac{w^{*}-w}{w^{*}+w} \equiv \widehat{a} \in[0,1]$.

Figure 1 describes the microeconomic relationship between migrants' skills $(h)$ and the optimal amount of remittances, $T^{*}(h)$. We only depict the situation where the interior maximum $h_{m}$ is larger than $h_{0} \cdot{ }^{5}$ We see that the optimal amount of remittances $T^{*}$ is first proportional to the migrant's education level (for $h<h_{0}$ ), is then increasing and concave for intermediate levels of education (between $h_{0}$ and $h_{m}$ )

\footnotetext{
${ }^{5}$ The other case where the maximum $h_{m}$ is lower than $h_{0}$ is very similar to Figure 1 , except that the linear segment of the transfer curve, $T_{0}(h)$, intersects with the concave part, $T(h)$, at the right of its maximum attained with $h=h_{m}$. Remittances increase linearly with education when $h<h_{0}$ and decrease for higher levels of education. Again, an inverted-U shaped function is obtained.
} 
and finally decreases with education for higher levels of education (between $h_{m}$ and $h_{1}$ ). An increase in the restrictiveness of immigration policy (a higher $c$ ) shifts the transfer curve outwards, as depicted by the grey dashed line: all the critical values $h_{0}, h_{1}$ and $h_{m}$ are increased (this is why they are expressed as functions of $c$ and $a$ ). In contrast, an increase in the selectivity of the immigration policy (a higher $a$ ) shifts the transfer curve inwards, unambiguously reducing $h_{0}, h_{1}$ and $h_{m}$ and making the segment $\left[0, h_{0}\right]$ shorter. Using $(8)$, the effect on $h_{m}$ is given by

$$
\frac{\partial h_{m}}{\partial a}=\frac{-h_{m}^{1+a} \ln h_{m}}{(1+a) a}<0
$$

This expression is clearly negative given that $h$ and therefore $h_{m}$ are greater than 1 .

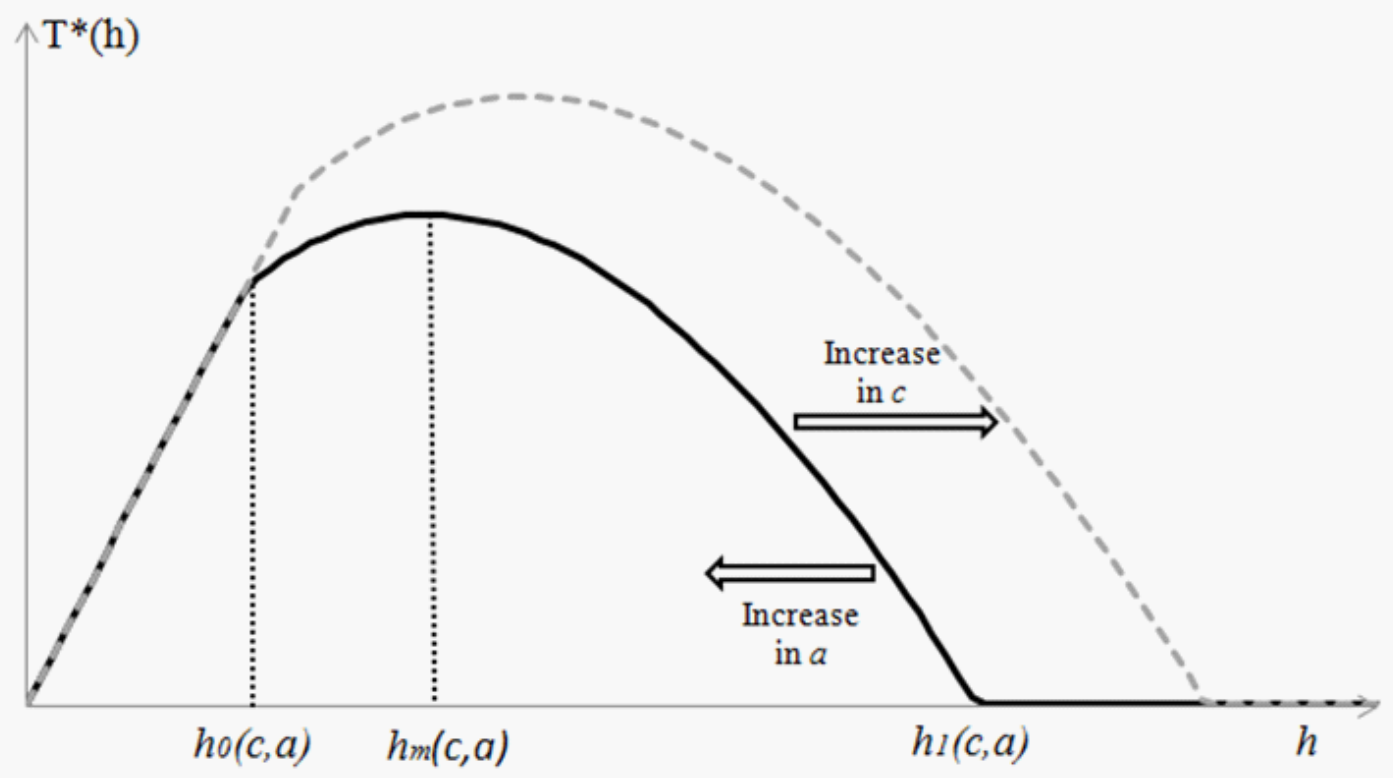

Figure 1: Remittances and migrants' education level

What are the implications for the macroeconomic analysis of remittances and skill composition of migration? If we have two groups of migrants (the highly skilled with $h=h^{s}$, and the low skilled with $\left.h=h^{u}<h^{s}\right)$, the excess amount remitted by a highly skilled $\Delta \equiv\left(T^{s}-T^{u}\right) / T^{u}$ is given by: 


$$
\Delta=\left\{\begin{array}{l}
\frac{T_{0}^{*}\left(h^{s}\right)-T_{0}^{*}\left(h^{u}\right)}{T_{0}^{*}\left(h^{u}\right)}>0 \text { if } h^{u}<h^{s}<h_{0}<h_{1} \\
\frac{T^{*}\left(h^{s}\right)-T_{0}^{*}\left(h^{u}\right)}{T_{0}^{*}\left(h^{u}\right)} \gtrless 0 \text { if } h^{u}<h_{0}<h^{s}<h_{1} \\
\frac{T^{*}\left(h^{s}\right)-T^{*}\left(h^{u}\right)}{T_{0}^{*}\left(h^{u}\right)} \gtrless 0 \text { if } h_{0}<h^{u}<h^{s}<h_{1} \\
-1<0 \text { if } h_{0}<h^{u}<h_{1}<h^{s} \\
0 \text { if } h_{0}<h_{1}<h^{u}<h^{s}
\end{array}\right.
$$

In other words, although the microeconomic relationship (1) between remittances and migrants' skill level $T^{*}(h)$ can be non-monotonic, $\Delta$ can only be positive or negative when only two groups of workers can be distinguished. However the sign and magnitude of $\Delta$ depend on the range of the observed skill levels $\left[h^{u}, h^{s}\right]$. If the maximum of the transfer curve, $h_{m}$, is such that $h^{s}<h_{m}$, then $\Delta$ is unambiguously positive. If $h_{m}<h^{u}$, then $\Delta$ is unambiguously negative. And if $h^{u}<h_{m}<h^{s}$, then $\Delta$ can be positive or negative.

In addition, interesting predictions on the role of immigration policies can be derived from this model. As illustrated on Figure 1, the shape of the transfer curve depends on the restrictiveness and selectivity of immigration policies at destination. Hence, the aggregate relationship between remittances and education is likely to vary with the characteristics of destination countries. More precisely:

- The higher the restrictiveness of the immigration policy at destination $(c)$, the larger the segment on which remittances increase with education. Hence, $\Delta$ is more likely to be positive. In more restrictive destination countries, aggregate remittances are more likely to be positively correlated with the immigrants' education level.

- The higher the selectivity of the immigration policy at destination $(a)$, the smaller the segment on which remittances increase with education. Hence, $\Delta$ is more likely to be negative. In more selective countries, aggregate remittances are more likely to be negatively correlated with the immigrants' education level.

To test these predictions we need bilateral data on remittances, on the size and structure of migration, and measures of the restrictiveness and selectivity of immigration policies. Our empirical strategy will consist in estimating eq. (1) treating $\Delta$ as a coefficient. Using interactions between our variable of interest (the skill composition of migration) and regional dummies as well as more direct proxy measures for immigration policies, we will estimate the effect of immigration policies at destination on the sign and intensity of $\Delta$. 


\subsection{Determinants of $\sigma_{i j t}$}

In the empirical analysis, migration stocks and compositions will be treated as exogenous regressors. This may appear as a limitation since migration is clearly an endogenous process affected by the same set of determinants as the amount of remittances per migrants. Indeed, the endogeneity of migration is a straightforward prediction of our model. The optimized utility level at destination $V^{*}(h)$, can be obtained by plugging (7) into (5). The utility of staying at home, on the other hand, is simply given by $V^{0}(h)=2 \ln (w h)$. Re-introducing bilateral notations (i.e. country and time subscripts), migration from country $i$ to country $j$ is desirable for type- $k$ individuals at time $t$ if

$$
V_{i j t}^{*}\left(h^{k}\right)-x_{i j t}\left(c, h^{k}\right)+\epsilon_{i j t}>V_{i i t}^{0}\left(h^{k}\right)+\epsilon_{i i t}
$$

where $x_{i j t}(c, h)$ is the migration costs for the household head, which depends on the restrictiveness of the immigration policy $\left(\partial x_{i j t} / \partial c>0\right)$ and of its selectivity in country $j$ (governing $\partial x_{i j t} / \partial h<0$ ), and $\epsilon$ stands for bilateral random terms (as in Roy, 1951, or Borjas, 1987).

When the random term follows an iid extreme-value distribution, we can apply the results in McFadden (1974) to write the log-ratio of emigrants to country $j\left(M_{i j t}^{k}\right)$ to residents $\left(M_{i i t}^{k}\right)$ as

$$
\ln \frac{M_{i j t}^{k}}{M_{i i t}^{k}}=V_{i j t}^{*}\left(h^{k}\right)-V_{i i t}^{0}\left(h^{k}\right)-x_{i j t}\left(c, h^{k}\right)
$$

It is obvious that these bilateral migration rates depend on the same determinants of as the remittances per migrant (i.e., on skill prices and on the parameters that characterize the immigration policies) and that they vary with the migrants' level of education. Consequently, the migration stocks $M_{i j t}^{s+u}$ and its skill composition $\sigma_{i j t}$ used in (1) are likely to be correlated with $\Delta_{i j t}$. This reinforces the choice of our empirical strategy just described in the previous sub-section to allow $\Delta$ to vary with the restrictiveness and selectivity immigration policies (through interaction terms) at destination.

\section{Data}

To examine the relationship between remittances and the skill level of migrants, we construct a new comprehensive bilateral data set documenting the amount of remittances sent by transferring country $j$ to recipient country $i$ at time $t$ (denoted by $R_{i j t}$ ), and the size and structure of bilateral migration stocks from origin country $i$ to destination country $j$. We denote by $M_{i j t}^{k}$ the stock of migrants with education level $k$. 


\subsection{Bilateral migration data}

Migration data are taken from Docquier et al. (2010) who construct 195x195 matrices of bilateral migration stocks for 1990 and 2000. The matrices are computed for two skill groups: migrants with college (tertiary) education, referred to as high-skill, and with less than college education (primary and secondary), referred to as low-skill. The methodology used in Docquier et al. (2010) consists of three steps. The starting point is the database described in Docquier, Lowell and Marfouk (2009) documenting bilateral migration stock to OECD host countries. It is based on a collection of census and register immigration data by country of birth and educational level in the 30 OECD countries. The second step consists of a collection of similar immigration data from 46 non-OECD destinations in 2000 and 31 destinations in 1990. Finally, data collected in steps 1 and 2 are used to predict the size and structure of migration to the remaining 119 non-OECD host countries in 2000 (and 134 in 1990). Gravity regression models were estimated for the size of bilateral migration from country $i$ to country $j$ in the education group $k$. The latter constructed data will not be used in our empirical analysis, which only builds on primary census data.

\subsection{Bilateral remittances}

The main difficulty is to obtain a large database on bilateral remittances. Our data set combines five existing databases constructed by other authors or organizations.

\subsubsection{Primary sources}

We use the following primary sources of data:

- The EU database (labeled as database I) is documented in a report of JimenezMartin, Jorgensen and Labeaga (2007) for the European Commission. It provides yearly bilateral remittances data from $16 \mathrm{EU}$ origin countries ${ }^{6}$ to 33 destinations ${ }^{7}$ from 2000 to 2005 . The database is unbalanced and includes a total of 337 observations covering 89 pairs of countries. To construct this database the authors relied mainly on the National Balance Sheet of Payment Statistics, the Second EU Survey on worker's remittances from the EU to third countries, surveys based on micro-level data, and data from various less important sources.

- The IMF database (labeled as database II) is documented in the paper by Lueth and Ruiz-Arranz (2008), two researchers from the International Mone-

\footnotetext{
${ }^{6}$ Belgium, Cyprus, France, Germany, Greece, Hungary, Ireland, Italy, Latvia, Lithuania, Netherlands, Poland, Portugal, Slovenia, Spain, United Kingdom

${ }^{7}$ Albania, Algeria, Argentina, Armenia, Bangladesh, Belarus, Bolivia, Brazil, Bulgaria, China, Colombia, Dominican Republic, Ecuador, Egypt, Georgia, Ghana, Israel, Jordan, Lebanon, Libya, Moldova, Morocco, Nigeria, Pakistan, Peru, Romania, Suriname, Syria, Tunisia, Ukraine, United States, Venezuela
} 
tary Fund. It distinguishes 69 remittances sending countries ${ }^{8}$ and 11 recipient countries from Asia and Europe (Bangladesh, Croatia, Indonesia, Kazakhstan, Macedonia, Moldova, Philippines, Serbia and Montenegro, Slovenia, Tajikistan, Thailand $)^{9}$ that break down their remittance receipts by country of origin and spans the period 1980-2005. The panel is unbalanced and includes a total of 1650 observations covering 200 country pairs. Remittance data (in USD) was provided by the recipient countries which produce estimates of inward remittances by paying countries using a variety of sources, including the International Transaction Recording System (ITRS), migrant surveys and statistics, as well as statements and surveys from banks and money operators. The bilateral flows captured in this data set account for nearly 90 percent of all remittances recorded in the balance of payments of these countries.

- The Romanian database (labeled as database III) is documented in the paper by De Sousa and Duval (2010). It provides bilateral remittances data (in USD) from 17 countries (12 EU countries plus Canada, the United States, Israel, Turkey and Switzerland) to Romania and covers the period 2005-08. Four observations per year are provided by the authors. The panel is balanced. The main source is the National Bank of Romania where data by paying country have been collected.

- The IDB database (labeled as database IV) was built by the International Development Bank. It provides bilateral remittances data from the United States to 5 Latin American countries (Costa Rica, Dominican Republic, El Salvador, Guatemala and Panama) and covers the period 2003-04. The panel is balanced. The main source is the US balance of payment.

- The ECB database (labeled as database V) is documented in the paper by Schioupu and Siegfried (2006), two researchers from the European Central Bank. It provides bilateral remittances data from 21 European paying countries (19 EU countries, plus Norway and Switzerland) and other non EU countries ${ }^{10}$

\footnotetext{
${ }^{8}$ Armenia, Australia, Austria, Azerbaijan, Bahrain, Belarus, Belgium, Bosnia, Brunei, Canada, China, Croatia, Cyprus, Czech Republic, Denmark, Estonia, Finland, France, Georgia, Germany, Greece, Hong Kong, Hungary, Indonesia, Iraq, Ireland, Israel, Italy, Japan, Jordan, Kazakhstan, Korea, Kuwait, Kyrgyzstan, Latvia, Liberia, Lithuania, Luxembourg, Lybia, Macedonia, Malaysia, Malta, Moldova, Netherlands, New Zealand, Norway, Oman, Poland, Portugal, Qatar, Romania, Russia, Saudi Arabia, Serbia and Montenegro, Singapore, Slovak Republic, Slovenia, Spain, Sweden, Switzerland, Taiwan Province of China, Tajikistan, Turkey, Turkmenistan, Ukraine, United Arab Emirates, United Kingdom, United States, Uzbekistan

${ }^{9}$ Latin American countries have been excluded on purpose by the authors since most of their remittances originate in the United States, and this corridor has been widely studied by the Inter American Development Bank. See database IV below.

${ }^{10}$ Algeria, Australia, Bahrain, Cameroon, Canada, Chad, China, Congo, Cyprus, Cote d'Ivoire, Egypt, Estonia, Ethiopia, Gabon, Guinea, Iraq, Israel, Japan, Jordan, Kuwait, Latvia, Lebanon, Libya, Lithuania, Mali, Malta, Mauritania, Morocco, Niger, Oman, Qatar, Russia, Rwanda, Saudi
} 
to 9 recipient countries (Algeria, Egypt, Morocco, Tunisia, Croatia, Macedonia, Serbia and Montenegro, Romania, Russia) ${ }^{11}$ and covers the period 2000-05. The panel is unbalanced.

Since each original database (except the IDB one) is unbalanced with respect to either the year of reference or the list of origins/destinations, we extended them over time and/or space in order to make them as balanced as possible and compatible with each other. The procedure consists in three steps:

\subsubsection{Creation of missing triplets and censoring}

We refer to a data point containing information on remittances from a given origin to a given source at a given year as a "triplet". Four out of five of the remittances databases to be merged are unbalanced with respect to at least one of these three dimensions. We create the missing triplets starting first by constructing the missing origin/destination country pairs and then by plugging the corresponding reference years. Once the missing triplets have been created in each original remittances data set, their remittances value has been censored to zero. ${ }^{12}$ Our guiding assumptions here is that the authors of the original data sets did not report data points that were below a certain critical value (unknown to us). In other terms we assumed that the amount of money transferred was negligible, that is, almost equal to zero for the missing pairs of countries. There are two situations in which missing values have not been censored. First, for missing values belonging to a triplet already present in another data set for which a positive value of remittances is available, and second when the missing value of remittances belongs to a triplet which is situated between two time-specific triplets for which positive values of remittances are available. In the first case, the same amount of remittances has been transferred over the same triplet from one data set to another. While in the second case, the mean of the two positive observed values belonging to the previous and the following triplet has been estimated to replace the missing one. ${ }^{13}$

As far as the EU database is concerned, missing couples have been created expanding the list of remittances receiving countries up to the full sample of 44 countries obtained after the aggregation of the 5 databases. The new couples created refer to

Arabia, Senegal, Slovenia, South Korea, Syria, Togo, Turkey, Ukraine, United Arab Emirates, United States, Yemen

${ }^{11}$ For these countries the data come from their national central banks, except for Morocco where they come from the Office des Changes.

${ }^{12}$ The EU database has the highest percentage (89\%) of created zeroes, followed by IMF $(66 \%)$, Romania (62\%) and ECB (61\%).

${ }^{13}$ We only interpolated four cells in the EU database. For each of the following triplets, Brazil Spain 2002, Ecuador Spain 2002, Peru Spain 2002 and United States Spain 2002, we did not censored the missing remittances value to zero but we computed the mean value between the observed remittances in year 2001 and 2003. 
the same period of time belonging to the balance of payment or to the surveys used by the transferring country. ${ }^{14}$

For the IMF data set, missing couples have been generated expanding the list of paying countries up to the full sample of 89 countries obtained after the aggregation of the 5 databases. The new couples created refer to the same length of time of the balance of payment used by the receiving country. ${ }^{15}$ For the Romanian database, missing observations for the year 2005 have been created by expanding the list of paying countries up to the full sample of 89 countries obtained after the aggregation of the 5 databases. For the IDB data set we did not add any empty cells since the data set is balanced from the beginning. Finally, for the ECB data set, missing couples have been created expanding the list of paying countries up to the full sample of 89 countries obtained after the aggregation of the 5 databases and refer to the same period of time considered by the data source. ${ }^{16}$

\subsubsection{Merging the five data sets}

The aggregation ${ }^{17}$ of these different sources gives an unbalanced database documenting bilateral transfers from 89 countries to 46 recipient countries. There are 13865 observations (2772 observations, 4 interpolated values and 11089 constructed zeroes) for 1969 origin-destination country pairs.

The sending countries are: Algeria, Armenia, Australia, Austria, Azerbaijan, Bahrain, Belarus, Belgium, Bosnia and Herzegovina, Brunei Darussalam, Cameroon, Canada, Chad, China, Congo, Cote d'Ivoire, Croatia, Cyprus, Czech Republic, Denmark, Egypt, Estonia, Ethiopia, Finland, France, Gabon, Georgia, Germany, Greece, Guinea, Hong Kong SAR, Hungary, Indonesia, Iraq, Ireland, Israel, Italy, Japan, Jordan, Kazakhstan, Korea, Kuwait, Kyrgyzstan, Latvia, Lebanon, Liberia, Libya, Lithuania, Luxembourg, Macedonia, Malaysia, Mali, Malta, Mauritania, Moldova, Morocco, Netherlands, New Zealand, Niger, Norway, Oman, Poland, Portugal, Qatar,

\footnotetext{
${ }^{14}$ Belgium from 2002-2004, Cyprus from 2002-2005, France from 2002-2005, Germany from 20002005, Greece from 2000-2005, Hungary from 2000-2005, Ireland 2002-2005, Italy 2000-2005, Latvia 2000-2005, Lithuania 2000-2005, Netherlands 2000-2005, Poland for 2004, Portugal 2000-2005, Slovenia 2004-2005, Spain 2001-2005, United Kingdom 2004-2005

${ }^{15}$ Bangladesh from 1985-2005, Croatia from 1997-2005, Indonesia from 2003-2005, Kazakhstan from 2003-2005, Macedonia from 1997-2005, Moldova from 2003-2005, Philippines from 1985-2004, Serbia from 2000-2005, Slovenia from 1994-2004, Tajikistan from 2002-2005 and Thailand from 1993-2004

${ }^{16}$ Algeria for 2003-2004, Egypt for 2001-2003, Morocco for 2000-2003, Tunisia for 2001-2003, Croatia for 2000-2004, Macedonia for 2003-2004, Serbia and Montenegro for 2004, Romania for 2005 and Russia for 2004

${ }^{17}$ There are 875 double triplets in the new aggregated remittances'dataset. In case a specific triplet (origin, destination and year) appears with positive values in two different original datasets we proceed in this way. We keep it since the correlation within each double is very high and perform the estimations with and without doubles using dummies in order to control for it. As expected, results are robust to the different specifications.
} 
Romania, Russia, Rwanda, Saudi Arabia, Senegal, Serbia and Montenegro, Singapore, Slovak Republic, Slovenia, South Korea, Spain, Sweden, Switzerland, Syria, Taiwan Province of China, Tajikistan, Togo, Turkey, Turkmenistan, Ukraine, United Arab Emirates, United Kingdom, United States, Uzbekistan, Yemen.

The recipient countries are: Albania, Algeria, Argentina, Armenia, Bangladesh, Belarus, Bolivia, Brazil, Bulgaria, China, Colombia, Costa Rica, Croatia, Dominican Republic, Ecuador, Egypt, El Salvador, Georgia, Ghana, Guatemala, Indonesia, Israel, Jordan, Kazakhstan, Lebanon, Libya, Macedonia, Moldova, Morocco, Nigeria, Pakistan, Panama, Peru, Philippines, Romania, Russia, Serbia and Montenegro, Slovenia, Suriname, Syria, Tajikistan, Thailand, Tunisia, Ukraine, United States, Venezuela.

\subsubsection{Couples for which migration data are missing}

For many immigration countries in the remittance database, Docquier et al (2010) have collected census data on the size and structure of migration. A first problem is that migration data are only available for 1990 and 2000, while remittances data goes from 1985 to 2005 . In the aggregate database, we will use the 1990 migration structure for the years 1985-1995, and the 2000 structure for the years 1996-2005. This should not distort too much our empirical analysis since migration data are based on sluggish migration stocks (not migration flows).

Another problem is that the migration database only documents the structure of immigration of 52 destination countries out of the 89 destinations in remittances database. For the remittances data to be consistent with the migration data, the number of migration destinations (remittances sending countries) is limited to 52 countries while the sample of migration origins does not change (i.e. 46 countries ${ }^{18}$ ). ${ }^{19}$ For example, in the migration data set we deal with, countries such as China, Russia or Tunisia are not contained into the destinations' sample. So even though remittances data from these destinations are available (such as remittances data from China to Algeria, or from Russia to Croatia, or Tunisia to Senegal), these couples cannot be considered and have therefore been excluded. Hence, the intersection of the above remittances and the migration databases gives rise to a data set going from 1985

\footnotetext{
${ }^{18}$ Among the final sample of origin countries there are 44 developing countries and 2 developed ones. The developed countries are Israel and United States.

${ }^{19}$ The final list of 52 remittances sending countries is: Australia, Austria, Bahrain, Belarus, Belgium, Canada, Cote d'Ivoire, Croatia, Cyprus, Czech Republic, Denmark, Estonia, Finland, France, Germany, Greece, Guinea, Hungary, Iraq, Ireland, Israel, Italy, Japan, Kuwait, Kyrgyzstan, Latvia, Lithuania, Luxembourg, Macedonia, Malaysia, Malta, Morocco, Netherlands, New Zealand, Norway, Oman, Poland, Portugal, Romania, Rwanda, Saudi Arabia, Singapore, Slovak Republic, Slovenia, South Korea, Spain, Sweden, Switzerland, Turkey, United Arab Emirates, United Kingdom, United States. The World Bank has recently published a comprehensive dataset on remittances and migration. For a list of the most important sending countries in a macro setting see World Bank (2011), pp. $15-16$
} 
to 2005 in which 8928 observations for 1348 country pairs are available. ${ }^{20}$ As far as remittances data are concerned, Table 1 shows that the 8928 final observations include 4 interpolated values, 6569 imputed zeroes and 2355 observed positive values. Discriminating by data set, the EU database contains 3058 final observations, 328 positive observed values, 2726 imputed zeroes and 4 interpolated values (2730 missing triplets). The IMF data set contains 4834 final observations, 1620 positive observed values, 3214 imputed zeroes (3214 missing triplets) and 196 true zeroes. $^{21}$ The Romanian data set contains 45 final observations, 17 positive observed values, 28 imputed zeroes (28 missing triplets). The IDB database keeps 10 final observations. The ECB data set has 981 final observations, 380 positive observed values, 601 imputed zeroes (601 missing triplets).

Table 1: Composition of the final database

\begin{tabular}{lcccccc}
\hline \hline & Final Database & EU & IMF & Romanian & IDB & ECB \\
\hline Total observations & 8928 & 3058 & 4834 & 45 & 10 & 981 \\
Interpolated values & 4 & 4 & - & - & - & - \\
Imputed zeroes & 6569 & 2726 & 3214 & 28 & - & 601 \\
Observed positive values & 2355 & 328 & 1620 & 17 & 10 & 380 \\
\hline \hline
\end{tabular}

\subsubsection{Some descriptive statistics}

Table 2 reports some descriptive statistics concerning the two main variables of interest. The first set of data (top of the table) concern the average amount of remittances per migrant. We divide the amount of bilateral remittances obtained from the combined database, by the number of bilateral migrants obtained from the DocquierLowell-Marfouk's database. As the migration population in the latter data set is restricted to individuals aged $25+$, our descriptive statistics overestimate the actual amount per migrants. Database fixed effects used in the regressions will address this problem. The second set of data (bottom of the table) reports the skill-ratio in bilateral migration, measured as the ratio of college graduates to less educated migrants. For each variable, we considered low and high-income destinations as well as different group of countries.

The average level of remittances per migrant is 1,023 USD. Nevertheless, the dispersion of per remittances per migrant is very high, depending on the level of development, geographic and immigration policy of destination countries. The mean

\footnotetext{
${ }^{20}$ As far as the timing issue is concerned, we use the yearly observations for remittances for the whole period covered (1985-2005). For migration, we have only two observations per country pair: 1990 and 2000. Given the persistence in the migration data we assume that migration in 1990 is a good approximation for real migration stocks from 1985 to 1995 and that migration in 2000 is a good approximation for real migration stocks from 1995 to 2005.

${ }^{21}$ The IMF database is the only dataset which contains true observed zeroes. Examples of triplets whose observed values are true zero are: China Latvia 2003, Philippines Denmark 2000, Thailand United Arab Emirates 1998.
} 
level of skill ratio is equal to 0.51 with higher level if high-income and point-system destination countries.

Table 2. Summary statistics

\begin{tabular}{lccc}
\hline \hline Variable & \# Obs. & Mean & Std. Dev. \\
\hline Remittances per migrant 25+ & & & \\
Full dataset & 6,822 & 1,023 & 4,108 \\
Low-income destinations & 190 & 26 & 206 \\
High-income destinations & 6,632 & 1,051 & 4,163 \\
EU destinations & 3,571 & 911 & 3,645 \\
GCC destinations & 620 & 1,732 & 3,824 \\
Western off-shoots destinations & 475 & 654 & 1,324 \\
Point-system destinations & 351 & 336 & 885 \\
\hline Skill ratio in bilateral migration 25+ & & & \\
Full dataset & 8,834 & 0.51 & 0.88 \\
Low income destinations & 556 & 0.10 & 0.25 \\
High Income destinations & 8,278 & 0.54 & 0.90 \\
EU destinations & 3,755 & 0.47 & 0.49 \\
GCC destinations & 704 & 0.20 & 0.13 \\
Western off-shoots destinations & 476 & 1.91 & 1.47 \\
Point-system destinations & 352 & 1.86 & 1.36 \\
\hline \hline
\end{tabular}

\subsection{Other data}

We use bilateral data on distance, geographical contiguity, colonial links, linguistic links. Those variables are time-invariant and come from the CEPII data which is based on population-weighted bilateral distances between the biggest cities at origin and destination (see Clair et al., 2004). Proxies capturing immigration policies will be explained in Section 4.4.

\section{Econometric Analysis}

\subsection{Related Literature}

The empirical specification adopted in this paper consists in a gravity model already used by Lueth and Ruiz-Arranz (2008) where the educational level of the migrants, as in Schioupu and Siegfried (2006), is introduced. In Lueth and Ruiz-Arranz (2008), one basic and two extended gravity models are estimated. The logarithmic transformation of the total amount of bilateral remittances (expressed in US dollars) is first regressed over the total and per capita gross domestic product at origin and destination plus a vector of bilateral variables such as the physical and linguistic distances between the two countries. In a first extension, the log of the bilateral stock of migrants is introduced as additional regressor and, finally, in a second extension, the log of the imports and exports, the stock market return and inflation differentials, depreciation of the home versus host country currency, various home and host 
country characteristics, and time fixed effects. The authors estimate the basic and the first extension of the above model accounting for origin and destination country (and region) fixed effects (leaving aside unobserved bilateral characteristics) and then country pair random effects (leaving aside origin and destination features). The second extension has been instead estimated with POLS. The authors find that the gravity equation is very powerful in explaining remittance flows. Indeed, in the base model, the standard gravity factors alone can explain more than half of the variation in bilateral remittance flows. As expected the size of the origin and destination countries positively affect the size of remittances, and distance has a negative effect. Contiguity has a negative or non significant effect, suggesting that sharing a border may facilitate non official transfers. Language has a positive sign suggesting that cultural affinities matter and, finally, more remittances are sent from countries with high GDP per capita to low income countries. Once the stock of migrants is added in the first extension, the authors find that the additional regressor is very significant and, as expected, positive. Finally, beyond the standard gravity factors, the authors find a number of variables to be significant in explaining remittances flows. Trade has a positive impact and, in particular, more remittances are sent from destinations of the home country's exports. Higher inflation in the home country is found to encourage more remittance flows, probably to compensate for the loss of purchasing power. The regression results also confirm that receiving countries' financial development and political stability matter. ${ }^{22}$

In Schioupu and Siegfried (2006), the log of bilateral remittances per migrant (obtained by dividing the log of total remittances by the migrant stock) is regressed over a vector of bilateral variables such as the differential rate of return on financial assets, income differentials (ratio of GDP per capita), and bilateral migration. Besides, another vector contains origin variables such as the skill level of the migrants (data are from OECD), income inequality, remittance costs, unofficial economic activity. Country of destination and time fixed effects are included. The authors find that GDP per capita differentials between sending and receiving countries is positively correlated with the average remittance per migrant. By contrast, interest rate differentials are not significant. A large informal economy in the paying country depresses official remittance flows. Finally and most importantly from our perspective, they find that the share of low-skill workers among migrants leads to lower remittances, suggesting that higher migrants'skill levels contribute to raise remittances.

\footnotetext{
${ }^{22}$ See also Yang (2008) on exchange rates fluctuations as a source of exogenous variation in household income from remittances, Giuliano and Ruiz-Arranz (2009) for a deeper analysis on the relationship between remittances and financial development using aggregate data, and Freund and Spatafora (2008) for an analysis of the determinants of formal v. informal remittances.
} 


\subsection{Basic specification}

The basic regression model follows eq. (1). We have no empirical counterpart for $\ln T_{i j t}^{u}$, the log of transfer per low-skilled migrant. We will introduce different sets of fixed effects and potential bilateral correlates (geographic distance, linguistic proximity) to capture it. In addition, we use the bilateral skill ratio in the migrant population aged $25+$, measured as the ratio of college graduates to less educated migrants plus one, ${ }^{23}$ as a proxy for $\sigma_{i j t} .{ }^{24}$ Our empirical model writes as follows:

$$
\begin{aligned}
\ln R_{i j d t}= & \eta_{i}+\eta_{j}+\eta_{d}+\eta_{t}+\alpha_{0}+\alpha_{1} \ln M_{i j t}^{s+u}+\alpha_{2} S_{i j t} \\
& +\alpha_{3} \ln D_{i j}+\alpha_{4} L_{i j}+\alpha_{5} Y_{i t}+\alpha_{6} Y_{j t}+\epsilon_{i j t}
\end{aligned}
$$

where $\ln R_{i j d t}$ measures total remittances in US dollars in logs from transferring (i.e. immigration) country $j$ to recipient (i.e. emigration) country $i$ at time $t$ in data set $d, \ln M_{i j t}^{s+u}$ is the $\log$ of the bilateral migration stock from $i$ to $j$ and $S_{i j t}$ is the skillratio, and $\ln D_{i j}$ and $L_{i j}$ are two bilateral variables accounting for geographical and linguistic distances. Origin, destination, time and database fixed effects are included. We also control for nominal GDP at origin and destination $\left(Y_{i t}\right.$ and $\left.Y_{j t}\right)$. The main coefficient of interest $\alpha_{2}$ will inform us about the average level of $\Delta_{i j t}$.

The estimation of the equation (10) entails various econometric issues ${ }^{25}$ that may lead the OLS estimation to generate inconsistent estimates. Moreover, there is a large proportion of zeros for the dependent variable (bilateral remittances) due to the fact that we constructed our comprehensive database on remittances to make it as balanced as possible, as extensively discussed in Section 3.

If OLS were to be used with the size of bilateral remittances as dependent variable, the estimates are likely to be inconsistent. One alternative is to use the natural log of bilateral remittances. However, the zero observations are dropped from the sample in such specifications since the natural log of zero is undefined. In that case, the results

\footnotetext{
${ }^{23}$ In line with Grogger and Hanson (2011).

${ }^{24} \mathrm{We}$ are unable, however, to use a variable capturing the vintage of the migration stock. The only dataset we are aware of where such information partly exists is Beine et al. (2007). In that data set, the authors provide data on the fraction of skilled migrants arrived before ages 12, 18 and 21. This is not enough to compute the age of the stock (as there is no information on the age of the individuals at the time of the census) and, moreover, the data by age of entry is available for skilled workers only.

${ }^{25}$ Among others, there can be an endogeneity issue due to the relationship between remittances and migration. In the micro literature the presence of an implicit family loan arrangement can lead to circular family migration due to remittances (see Poirine, B. (1997): A Theory of Remittances as an Implicit Family Loan Arrangement, World Development, Vol. 25, N.4, 589-611) and this can presume that migration decision is endogenous. The empirical micro literature addressed such a reverse causality issue with instrumental variables' technique (see for example Bollard, A., D. McKenzie, M. Morten and H. Rapoport (2011): Remittances and the Brain Drain Revisited: The Microdata Show that More Educated Migrants Remit More, World Bank Economic Review, forthcoming). On the macro side, instead, the issue is a bit more difficult to address and this is due to the lower probability of finding an appropriate instrument. Indeed, nobody dealt with it untill now.
} 
are likely to be biased and the impacts of the explanatory variables are likely to be underestimated due to the exclusion of low value observations from the sample and the selection issue we addressed with the triplets reconstruction and censoring. Alternatively, one can add one to the size of bilateral remittances and then take the log. However, since the log of one is zero, this results in an excessive number of zeros in the estimated dependent variable, which also leads to heteroskedasticity in the estimation. The most appropriate solution to this problem is to use Poisson regression models that rely on pseudo-maximum likelihood estimates, as argued by Santos Silva and Tenreyro (2006). ${ }^{26}$ Accordingly, we implement Poisson regressions as our preferred specification. All the Poisson models are estimated with robust standard errors to militate against a further econometric complication: this relates to the fact that Poisson maximum likelihood estimation yields consistent point estimates even when the count is not strictly Poisson distributed (i.e., in case of overdispersion). Importantly in such circumstances, the estimated standard errors will be significantly smaller than if the count was strictly Poisson. This occurs when the conditional variance is greater than the conditional mean, that is, when the assumption of equidispersion is violated.

Table 3 provides estimation results for the base model in the full sample. Three different estimators are used. ${ }^{27}$ The first column provides OLS results when the dependent variable is expressed in log. The second column still provides OLS estimates but when the dependent variable is expressed as one plus the amount of bilateral remittances. This transformation allows us to keep the cases in which the level of remittances is equal to zero. Then the third and the fourth columns report estimates ${ }^{28}$ obtained with the Poisson estimator. Looking at the third column, as expected, the stock of migrants at destination is positive and significant, as well as the skill ratio (of skilled to unskilled migrants at destination). ${ }^{29}$ Additionally, geographical distance is negative and linguistic proximity is positive, as in Lueth and Ruiz-Arranz (2008), confirming the validity of gravity factors. As far as nominal GDP variables

\footnotetext{
${ }^{26}$ For example, they show that the log linearization of gravity models leads to inconsistent estimates of the coefficients of explanatory variables such as distance.

${ }^{27}$ From Table 4 onwards, only Poisson regressions are performed.

${ }^{28}$ Like any other regression coefficient, a Poisson regression coefficient represents the change in response corresponding to a one unit difference in the corresponding predictor. The Poisson regression coefficients have to interpreted as follows: for a one unit change in the predictor variable, the difference in the logs of expected counts is expected to change by the respective regression coefficient, given the other predictor variables in the model are held constant. If a dummy variable is present, the coefficient is equal to the difference in the logs of expected counts between the dummy variable itself and the base term, while holding the other variables constant in the model.

${ }^{29}$ In order to exclude the possibilty that remittances sent back from skilled people residing in the two developed countries (Israel and United States) contained in the final database include also the so called 'compensations of employees', we have performed the same estimations excluding these countries from the sample. As in the IMF Balance of Payments Statistics Yearbook (BOPSY), compensations of employees comprise wages, salaries, and other benefits earned by individuals in economies other than those in which they are residents, for work performed for and paid for by residents of those economies. Results are robust to the exclusion of the above origin countries and available on request.
} 
are concerned, and again similarly to the results in Lueth and Ruiz-Arranz (2008), the positive sign for the level of GDP at both origin and destination confirms that larger countries receive (and send) larger volumes of remittances in dollar terms.

\begin{tabular}{|c|c|c|c|c|c|c|}
\hline & \multicolumn{2}{|c|}{$\begin{array}{c}\text { OLS } \\
\ln (\text { Rijdt })\end{array}$} & \multicolumn{2}{|c|}{$\begin{array}{c}\text { OLS } \\
\ln (1+\text { Rijdt }) \\
\end{array}$} & \multicolumn{2}{|l|}{$\begin{array}{c}\text { Poisson } \\
\text { Rijdt } \\
\end{array}$} \\
\hline \multirow[t]{2}{*}{ Log of migrants'stock } & 0.288 & $* * *$ & 1.090 & $* * *$ & 0.832 & $* * *$ \\
\hline & 0.026 & & 0.026 & & 0.027 & \\
\hline \multirow[t]{2}{*}{ Log of distance } & 0.016 & & -0.003 & & -0.030 & * \\
\hline & 0.012 & & 0.023 & & 0.015 & \\
\hline \multirow[t]{2}{*}{ Common language } & 1.134 & $* * *$ & 0.079 & & 0.774 & $* * *$ \\
\hline & 0.142 & & 0.333 & & 0.134 & \\
\hline \multirow[t]{2}{*}{ Skill-ratio } & 0.003 & $* * *$ & 0.002 & $* *$ & 0.006 & $* * *$ \\
\hline & 0.000 & & 0.001 & & 0.001 & \\
\hline \multirow[t]{2}{*}{ GDP origin (log) } & -1.153 & & -1.515 & & 1.398 & $*$ \\
\hline & 0.760 & & 1.238 & & 0.771 & \\
\hline \multirow[t]{2}{*}{ GDP destination $(\log )$} & 1.272 & $* * *$ & 2.142 & $* * *$ & 1.626 & $* * *$ \\
\hline & 0.274 & & 0.364 & & 0.305 & \\
\hline \multirow[t]{2}{*}{ Constant } & 24.860 & & 6.776 & & -44.760 & $* *$ \\
\hline & 17.110 & & 27.380 & & 17.210 & \\
\hline Origin FE & yes & & yes & & yes & \\
\hline Dest FE & yes & & yes & & yes & \\
\hline Year FE & yes & & yes & & yes & \\
\hline Database FE & yes & & yes & & yes & \\
\hline $\mathrm{Nb}$ of observations & 2163 & & 8888 & & 8888 & \\
\hline Log pseudolikelihood & - & & - & & $-4.43 \mathrm{E}+10$ & \\
\hline F-stat/Wald chi2 & 47.46 & & 486.77 & & 152663.4 & \\
\hline $\mathrm{R} 2$ & 0.742 & & 0.4857 & & 0.9125 & \\
\hline Hettest p-value & 0 & & 0 & & 0 & \\
\hline
\end{tabular}

Table 4 provides Poisson estimates by data set (the numbering of the columns corresponds to the numbering of the data sets in Section 3). ${ }^{30}$ The stock of migrants is always positive and highly significant. Geographical distance is always negative and significant, and linguistic proximity matters for the data sets with enough heterogeneity in this respect. Regarding our main coefficient of interest, estimation results are not stable across data sets: a higher skill ratio is positive and weakly significant in column I for the EU data set, not significant in column II for the IMF data set and negative and significant in column $\mathrm{V}$ for the ECB data set. ${ }^{31}$

In the following sections, therefore, we investigate whether differences in the results across data sets may be explained by differences in the composition of their samples of destination countries. More precisely, using insights from our theoretical

\footnotetext{
${ }^{30}$ Estimation results concerning database III and IV are not reported because of sample size. The former contains 45 observations while the latter just 10 .

${ }^{31}$ Evidently, the fact that our estimation results are different from Schioupu and Siegfried (2006) depend on many factors. First of all, the samples of interest are different after the creation of imputed zeroes. In their case, there are 239 observations against 981 in our case. We use Poisson estimator to account for such a large portion of zeroes while they estimate their model with an unbalanced panel estimator.
} 
model, we ask whether the dimensions of 'restrictiveness' and 'selectivity' of immigration policies in the different destinations can explain the sign and intensity of the relationship between remittances and migrants' education. Given the fact that there is currently no comparative bilateral data set on immigration policies, nor is there a synthetic or aggregate index of immigration policy restrictiveness or selectivity, we have rely on proxy measures for these dimensions (see the discussions in section 4.3.1). To the extent that different regions have different immigration policy traditions, we first use regional membership as a proxy for immigration policy in section 4.3.2 before turning to more specific aspects of immigration law and policy in section 4.3.3.

Table 4. Basic model Poisson estimations by data set

\begin{tabular}{|c|c|c|c|c|c|c|c|c|}
\hline \multirow{3}{*}{$\begin{array}{l}\text { Dependent: Rijdt } \\
\text { Log of migrants'stock }\end{array}$} & \multicolumn{2}{|l|}{$\mathrm{I}(\mathrm{EU})$} & \multicolumn{2}{|c|}{ II (IMF) } & \multirow{3}{*}{$\begin{array}{l}\text { III (Rom) } \\
-\end{array}$} & \multirow{2}{*}{$\frac{\text { IV (IDB) }}{-}$} & \multicolumn{2}{|l|}{$\mathrm{V}(\mathrm{ECB})$} \\
\hline & 0.790 & $* * *$ & 0.790 & **** & & & 0.478 & **** \\
\hline & 0.068 & & 0.035 & & & & 0.061 & \\
\hline \multirow[t]{2}{*}{ Log of distance } & -0.224 & $* * *$ & -0.086 & $* * *$ & - & - & -0.154 & $* * *$ \\
\hline & 0.032 & & 0.020 & & & & 0.035 & \\
\hline \multirow[t]{2}{*}{ Common language } & 1.808 & $* * *$ & 1.388 & $* * *$ & - & - & 0.652 & ** \\
\hline & 0.295 & & 0.169 & & & & 0.332 & \\
\hline \multirow[t]{2}{*}{ Skill-ratio } & 0.006 & $* * *$ & -0.177 & ** & - & - & -0.674 & \\
\hline & 0.001 & $* * *$ & 0.104 & & & & 0.474 & \\
\hline \multirow[t]{2}{*}{ GDP origin (log) } & 0.784 & & 1.185 & & - & - & 1.793 & \\
\hline & 2.398 & & 0.733 & & & & 7.710 & \\
\hline \multirow[t]{2}{*}{ GDP destination (log) } & -4.893 & $* *$ & 1.612 & $* * *$ & - & - & 3.231 & $* *$ \\
\hline & 2.124 & & 0.322 & & & & 1.611 & \\
\hline \multirow[t]{2}{*}{ Constant } & 44.665 & & -37.506 & & - & - & -64.894 & \\
\hline & 54.451 & & 19.004 & & & & 186.32 & \\
\hline Origin FE & yes & & yes & & - & - & yes & \\
\hline Dest FE & yes & & yes & & - & - & yes & \\
\hline Year FE & yes & & yes & & - & - & yes & \\
\hline $\mathrm{Nb}$ of observations & 3058 & & 4794 & & 45 & 10 & 981 & \\
\hline Log pseudolikelihood & $-1.30 \mathrm{E}+09$ & & $-2.95 \mathrm{E}+10$ & & - & - & $-3.67 \mathrm{E}+09$ & \\
\hline Wald chi2 & 232882 & & 992407 & & - & - & $9.32 \mathrm{E}+10$ & \\
\hline $\mathrm{R} 2$ & 0.884 & & 0.920 & & - & - & 0.927 & \\
\hline
\end{tabular}

\subsection{Specifications with interactions}

\subsubsection{Proxying for the dimensions of immigration policy}

Unfortunately, there is currently no decent comparative database on immigration policy as there are no comprehensive, cross-nationally comparable data on immigration laws and policies and no established method for classifying, measuring, and comparing laws and policies across countries and over time. As a consequence, it is extremely difficult for scholars to examine the causes and effects of different approaches to managing immigration. And still, we know that governments adopt a wide variety of approaches to regulating immigration. They give different meanings to basic concepts such as citizenship and residency, adopt different criteria for granting asylum and refugee status, and place different weights on occupational skills, family reunification, and cultural and ethnic diversity when selecting immigrants. 
Of course, there have been attempts to provide indicators of restrictiveness of international migration. These include among others Ortega and Peri (2009), Mayda (2010) and Belot and Ederveen (2011). From our perspective, however, all those indicators suffer however from a number of drawbacks. For instance, indicators based on policy reforms, such as those provided by Mayda (2010) are not comparable across countries: countries can relax their immigration restrictions and at the same time remain very restrictive compared to other potential destinations. Another issue is that one country might be very restrictive in one particular area of immigration policy while being quite liberal in another one. For instance the US has been traditionally quite liberal in attracting students and skilled workers and quite open in terms of family reunification while implementing increasingly tougher regulations on illegal immigration. Likewise, countries in Continental Europe are considered very generous in terms of family reunification while being very restrictive with respect to skilled and unskilled migrants. Finally, general indicators of entry restriction that aggregate immigration policies in different areas such as the indicator of Ortega and Peri (2009) tend to overlook the heterogeneity of migration policies within a given country.

There is now an important empirical literature exploring the determinants (push and pull factors) of the size and skill composition (selection) of international migration. This literature has notably emphasized the role of wage differentials (Grogger and Hanson, 2011), credit constraints (Belot and Hatton, 2011) and migration/diaspora networks (see McKenzie and Rapoport (2010) for a micro study on Mexico and Beine, Docquier and Ozden (2011) for a bilateral setting). A common limit to the papers in this literature, however, is that they either neglect the role of immigration policies or capture them through proxy variables such as the number of asylum seekers or the existence of bilateral agreements (e.g., EU membership, existence of visa waiver or of guest worker programs) between sending and receiving countries. Hence, this literature uses both bilateral variables (such as the existence of guest worker programs) and general policy orientations (such as the openness to refugees) as indicators of immigration policies at destination. We use a similar approach in section 4.3.3 where we proxy for the restrictiveness of immigration policy in the destination country using three proxy variables (existence of bilateral guest worker programs, proportion of refugees among migrants, and proportion of females among migrants - the latter being interpreted as an indicator of openness to family migration) and for its selectivity by the existence of a point-system. Noting that immigration policies also have a strong regional character (e.g., the EU is known to be less selective than the United States, Australia or Canada, and the member countries of the Gulf Cooperation Council all encourage temporary labor migration through guest-worker programs but discourage permanent family migration through very stringent citizenship laws and family reunion criteria), in section 4.3 .2 we use also use regional dummies as a proxy measure for the restrictiveness and/or selectivity of immigration policies. 


\subsubsection{Interactions with regional dummies}

We distinguish five groups of destination countries $(r=1, \ldots, 5)$ : Persian Gulf countries (Bahrain, Iraq, Kuwait, Oman, Saudi Arabia and United Arab Emirates), EU15 (the fifteen members of the European Union in 2000), Western offshoots (USA, Canada, Australia and New-Zealand), and either developing or rich country status for the remaining countries (using the World Bank classification). Based on a substantial literature, ${ }^{32}$ our assessment is as follows. First, as is well-known, the member countries of the Gulf Cooperation Council (GCC) favor temporary guest worker migration and are extremely reluctant to grant permanent status to migrant workers: we thus characterize these countries as being extremely restrictive and, therefore, expect a positive coefficient for the interaction between migrants' skill-ratio and the 'Gulf' dummy. Second, Europe is known for being relatively generous in terms of family reunion programs (low restrictiveness) while the non-European Anglo-Saxon countries (especially Canada, Australia and New-Zealand) are more skill-selective: we therefore expect a negative interaction term for both Europe (due to low restrictness) and the Western offshoots (due to high-selectivity). Finally, developing countries may be characterized as neither restrictive nor selective, two features that substitute one another in predicting the effect of migrants' education on remittances.

Table 5 provides regressions results introducing interactions with regional dummies (using the complete set of fixed effects) ${ }^{33}$ All coefficients on the interaction terms are in accordance to expectations. In particular the coefficient on the skill-ratio is positive and highly significant. Given that it is quite small, the sign and magnitude of the total effect of the skill ratio on remittances from different regions are fully determined by the interaction terms: largely positive in the Gulf countries, and largely negative in Europe and in the Western offshoots. Each interaction with geographic dummies can be interpreted in terms of marginal effect brought to the skill ratio by the nature of immigration policies at destination. In particular, the immigration policies conducted in the Gulf Countries make the skill ratio more effective at increasing remittances, while those conducted in European countries as well as in the Western offshoots act to reduce the amount of remittances sent home by skilled migrants. The interaction effect can be calculated as a double difference or the double derivative of the dependent variable with respect to the two components of the interaction. Calculations considering the Poisson coefficients for the variables GCC, EU, Western offshoots and Developing alone give the following marginal effects. The

\footnotetext{
${ }^{32}$ See for example Pritchett (2006) for a typology of immigration policies and characterization of these policies across regions.

${ }^{33}$ In order to control for the entire set of fixed effects we followed Santos Silva ans Tenreyro (2010). Step 1. For the observations with $R_{i j d t}>0$, estimate the ordinary least squares regression of $\ln \left(R_{i j d t}\right)$ on $x_{i}$. Step 2. Construct a subset of explanatory variables, say $\tilde{x}_{i}$. comprising only the regressors whose coefficients were estimated in Step 1. Step 3. Using the full sample, run the Poisson regression of $R_{i j d t}$ on $\tilde{x_{i}}$. We excluded distance as regressor because it was not significant in the first step.
} 
net marginal effect of "Gulf Countries" on remittances equals to 0.027 and to -0, 29 and -0,09 respectively for European countries and for the Western offshoots. The Poisson regression coefficients represent the change in response corresponding to a one unit difference in the corresponding predictor.

Table 5. Poisson regressions with regional interactions terms

\begin{tabular}{lrr}
\hline \hline Dependent: Rijdt & \multicolumn{2}{c}{ Full sample } \\
\hline Log of migrants'stock & 0.824 & $* * *$ \\
Skill-ratio (SR) & 0.029 & \\
& 0.005 & $* * *$ \\
SR X GCC & 0.0001 & \\
& 0.022 & $* * *$ \\
SR X EU & 0.003 & \\
& -0.3 & $* * *$ \\
SR X Western offshoots & 0.03 & \\
& -0.095 & $* * *$ \\
SR X developing & 0.004 & \\
& -0.001 & \\
Common Language & 0.015 & \\
& 0.744 & $* * *$ \\
GDP origin (log) & 0.134 & \\
& 0.265 & $* *$ \\
GDP destination (log) & 0.806 & \\
& 1.684 & $* * *$ \\
Constant & 0.307 & \\
& -42.051 & $*$ \\
Origin FE & 17.929 & \\
Destination FE & yes & \\
Year FE & yes & \\
Database FE & yes & \\
\hline Nb of observations & 8888 & \\
Log pseudolikelihood & $-4.70 \mathrm{E}+10$ & \\
Wald chi2 & 171350.58 & \\
Pseudo R2 & 0.9131 & \\
\hline \hline Robant at the 10\% level $* *$ & $5 \%$ level & $* * * 1$ \\
Roust standard errors below the estimates \\
\end{tabular}

\subsubsection{Interactions with policy measures}

The results in Table 5 support our conjecture that the effect of migrants' education should vary by destination to the extent that these destinations differ in terms of immigration policies. To reinforce our conclusions, we explore other interactions with proxy measures of various dimensions of immigration policies. The extended regression equation now writes as:

$$
\begin{aligned}
R_{i j d t}= & \eta_{i}+\eta_{j}+\eta_{d}+\eta_{t}+\alpha_{0}+\alpha_{1} \ln M_{i j t}+\alpha_{2} S_{i j t}+\alpha_{4} \ln D_{i j} \\
& +\alpha_{4} L_{i j}+\alpha_{5} Y_{i t}+\alpha_{6} Y_{j t}+\sum_{p} \beta_{p} S_{i j t} \pi_{i j p}+\epsilon_{i j t}
\end{aligned}
$$

where $\pi_{i j p}$ is a set of variables capturing a dimension $p$ of the immigration policy for the pair of countries $i$ and $j$ (sometimes only related to the immigration policy in the destination country $j$ ). Table 6 gives the regressions results with such interactions. 
As explained in section 4.3.1, due to lack of data we use proxies for the existence of temporary labor programs, strict entry policies, skill-biased restrictions, and family reunification programs.

The first policy measure we introduce is a bilateral dummy for the existence after 1990 of a guest worker program in destination country $j$ vis-à-vis origin country $i$ (Guest). This is a bilateral variable proxying for the cost of migrating permanently. Data on the existence of guest workers programs have been gathered using various sources, notably Basok (2000), Martin (2003), McDowell (2003), and Ruhs and Martin (2008). As can be seen from Column 1 in Table 6, the skill-ratio among migrants has a positive and highly significant effect on remittances when countries have guestworker agreements. Our estimate of the marginal effect of guest-worker agreements on the propensity to send remittances by skilled people is equal to 0.295.

The second immigration policy measure we introduce is the average proportion of refugees at destination (Refugees), calculated as the number of refugees at destination as a percentage of total international migration per year. Data are from UNHCR Statistical On line Population Database. In line with the literature on the determinants of international migration in a bilateral setting (Grogger and Hanson, 2011, Belot and Hatton, 2011, Beine, Docquier and Ozden, 2011, Ortega and Peri, 2009), we interpret 'taking many refugees' as a sign of low restrictiveness. As can be seen from Column 2 in Table 6, the interaction between the skill-ratio and the share of refugees among migrants is indeed negative, not enough though to dominate the positive direct effect of the skill-ratio on remittances. Our estimate of the marginal effect of a low restrictiveness policy on the propensity to send remittances by skilled people is equal to 0.042 .

The third aspect of immigration policy we want to introduce is the ease of family reunion, for which we use as proxy the share of females among immigrants (Family). We compute the absolute value of the difference between the proportion of females among migrants and one half. If the difference is small, we interpret this as pointing to the existence of relatively open and generous family reunion programs (i.e., low restrictiveness). ${ }^{34}$ The data are taken from Docquier et al. (2010). As can be seen from Column 3 in Table 6, the effect is positive, as expected (i.e., more restrictive destinations are associated with skilled migrants sending relatively more remittances). The marginal effect of costly family reunion immigration policies on the propensity to send remittances by skilled people is estimated to be equal to 0.267 .

Finally, Column 4 in Table 6 reports estimation results using a Point System interaction term: the skill composition of immigrants at destination is interacted with a dummy variable equal to 1 if the destination country (Australia, Canada, New Zealand) has a Point System. ${ }^{35}$ As expected, the sign of the coefficient of the

\footnotetext{
${ }^{34}$ See Morrison, Schiff and Sjoblom (2008).

${ }^{35}$ Since 1984, Australia's immigration policy has officially privileged skilled workers, with the candidates being selected according to their prospective 'contribution to the Australian economy'. Canadian immigration policy follows similar lines, resulting in an increasing share of highly educated
} 
interaction term is negative and highly significant. Our estimate of the marginal effect of skill biased immigration policies on the propensity to send remittances is equal to 0.79 .

Table 6. Poisson regressions with political interactions terms

\begin{tabular}{|c|c|c|c|c|c|c|c|c|}
\hline Dependent: Rijdt & (1) & & $(2)$ & & $(3)$ & & (4) & \\
\hline \multirow[t]{2}{*}{ Log of mig. stock } & 0.815 & $* * *$ & 0.813 & $* * *$ & 0.812 & $* * *$ & 0.814 & $* * *$ \\
\hline & 0.028 & & 0.027 & & 0.028 & & 0.027 & \\
\hline \multirow[t]{2}{*}{ Skill-ratio (SR) } & 0.0004 & $* * *$ & 0.0004 & $* * *$ & 0.0004 & $* * *$ & 0.0004 & $* * *$ \\
\hline & 0.0001 & & 0.0001 & & 0.0001 & & 0.0001 & \\
\hline \multirow[t]{2}{*}{ Guest } & 0.058 & & - & & - & & - & \\
\hline & 0.211 & & & & & & & \\
\hline \multirow[t]{2}{*}{ SR X Guest } & 0.295 & $* * *$ & - & & - & & - & \\
\hline & 0.060 & & & & & & & \\
\hline \multirow[t]{2}{*}{ SR X Refugees } & - & & $-3 e-005$ & $* *$ & - & & - & \\
\hline & & & $1.8 \mathrm{e}-005$ & & & & & \\
\hline \multirow[t]{2}{*}{ SR X FamilyCost } & - & & - & & 0.267 & $* * *$ & - & \\
\hline & & & & & 0.074 & & & \\
\hline \multirow[t]{2}{*}{ SR X Point-syst } & - & & - & & - & & -0.8 & $* * *$ \\
\hline & & & & & & & 0.206 & \\
\hline \multirow[t]{2}{*}{ GDP origin (log) } & 1.705 & $* *$ & 1.703 & $* *$ & 1.701 & $* *$ & 1.69 & $* *$ \\
\hline & 0.77 & & 0.772 & & 0.771 & & 0.776 & \\
\hline \multirow[t]{2}{*}{ GDP destination (log) } & 1.544 & $* * *$ & 1.541 & $* * *$ & 1.54 & $* * *$ & 1.539 & $* * *$ \\
\hline & 0.303 & & 0.301 & & 0.302 & & 0.299 & \\
\hline \multirow[t]{2}{*}{ Log of distance } & -0.028 & $*$ & -0.027 & $*$ & -0.023 & $*$ & -0.0284 & $*$ \\
\hline & 0.016 & & 0.016 & & 0.057 & & 0.015 & \\
\hline \multirow[t]{2}{*}{ Common Language } & 0.664 & $* * *$ & 0.663 & $* * *$ & 0.665 & $* * *$ & 0.664 & $* * *$ \\
\hline & 0.1372 & & 0.1371 & & 0.138 & & 0.135 & \\
\hline \multirow[t]{2}{*}{ Constant } & -50.157 & $* *$ & -48.13 & $* *$ & -34.2 & $* *$ & 25.157 & $* *$ \\
\hline & 17.243 & & 14.243 & & 17.3 & & 11.243 & \\
\hline Origin FE & yes & & yes & & yes & & yes & \\
\hline Destination FE & yes & & yes & & yes & & yes & \\
\hline Year FE & yes & & yes & & yes & & yes & \\
\hline Database FE & yes & & yes & & yes & & yes & \\
\hline Nb of observations & 8888 & & 8888 & & 8888 & & 8888 & \\
\hline Log pseudolikelihood & $-4.65 \mathrm{E}+10$ & & $-4.43 \mathrm{E}+10$ & & $-4.87 \mathrm{E}+10$ & & $-4.78 \mathrm{E}+10$ & \\
\hline Wald chi2 & 143552 & & 174552 & & 123852 & & 145352 & \\
\hline Pseudo R2 & 0.914 & & 0.913 & & 0.915 & & 0.914 & \\
\hline
\end{tabular}

\section{Conclusion}

This paper investigates the relationship between remittances and migrants' education both theoretically and empirically, using original bilateral remittances data. This is an important policy issue given the increasing reliance on remittances of many developing countries and the concomitant rise in migrants' skill levels due to supply-side (e.g., self-selection) and demand-side (generalization of quality-selective immigration policies of the point-system type) forces. Previous literature has been either inconclusive or produced conflicting results as to whether the highly educated temd to

people among the selected immigrants; for example, in 1997, 50,000 professional specialists and entrepreneurs immigrated in Canada with 75,000 additional family members, representing 58\% of total immigration. 
remit more or less. While macro studies using aggregate data found a negative effect of migrants education on total remittances, studies based on bilateral or micro data found a generally positive effect of education on expected remittances (neutral at the extensive margin, and positive at the intensive margin for the sample combining eleven household surveys in Bollard et al., 2011).

This paper partly reconciles the results from the existing literature by emphasizing the role of immigration policies in determining the nature of the relationship between remittances and migrants' education. We first propose a simple model of remittance behavior interacting migrants' human capital with two dimensions of immigration policies: restrictiveness, and selectivity. The model predicts that the relationship between remittances and migrants' education will be inverse- $U$ shaped and that for a given country pair, a more skilled pool of migrants will send more (resp. less) remittances if the destination country has a more restrictive (resp. selective) immigration policy. Using a new database obtained by merging various second-hand sources on bilateral remittances for a large set of country-pairs over the period 1985-2005, we test these predictions by interacting in our remittance regressions the skill composition of immigration with proxy measures for the restrictiveness and selectivity of immigration policies at destination. The results strongly support the theoretical analysis, suggesting that immigration policies in the migrants' host countries determine whether the home countries receive relatively more or less remittances from their skilled emigrants.

\section{References}

Ashraf, N., D. Aycinena, C. Martinez and D. Yang (2010): Remittances and the Problem of Control: A Field Experiment Among Migrants from El Salvador, Working Paper, University of Michigan Ford School of Public Policy.

Basok, T. (2000): He Came, He Saw, He ... Stayed. Guest Worker Programmes and the Issue of Non-Return, International Migration, 38, 2: 215-38.

Beine, M., F. Docquier and C. Ozden (2011): Diasporas, Journal of Development Economics, 95, 1: 30-41.

Beine, M., F. Docquier and H. Rapoport (2007): Measuring international skilled migration: new estimates controlling for age of entry, World Bank Economic Review, 21, 2: 249-54.

Belot, M. and S. Ederveen (2011): Cultural Barriers in Migration in OECD Countries, Journal of Population Economics, forthcoming.

Belot, M. and T.J. Hatton (2011): Immigrant selection in the OECD, Scandinavian Journal of Economics, forthcoming.

Bollard, A., D. McKenzie, M. Morten and H. Rapoport (2011): Remittances and the Brain Drain Revisited: The Microdata Show that More Educated Migrants Remit More, World Bank Economic Review, 25, 1: 132-156. 
Borjas, G (1987): Self-selection and the earnings of migrants, American Economic Review, 77 (4), 531-53.

Clair, G., G. Gaullier, Th. Mayer and S. Zignago (2004): A note on CEPII's distances measures - Explanatory note, CEPII, Paris.

De Sousa, J. and L. Duval (2010): Geographic Distance and Remittances in Romania: Out of Sight, out of Mind?, International Economics/Economie Internationale, 121, 1: 8198.

Docquier, F., B. L. Lowell and A. Marfouk (2009): A gendered assessment of the brain drain, Population and Development Review, 35, 2: 297-321.

Docquier, F., A. Marfouk, C. Ozden and C. Parsons (2010), Geographic, gender and skill structure of international migration, Report for the Economic Research Forum, Cairo.

Dustmann, C. and J. Mestres (2010): Remittances and Temporary Migration, Journal of Development Economics, 92, 1: 62-70.

Duval, L. and F.-C. Wolff (2010): Remittances matter: Longitudinal evidence from Albania, Post-Communist Economies, 22, 1: 73-97.

Faini, R. (2007): Remittances and the brain drain: do more skilled migrants remit more?, World Bank Economic Review, 21, 2: 177-91.

Frankel, J. (2011): Are bilateral remittances countercyclical?, Open Economies Review, 22, 1: 1-16.

Freund, C., and N. Spatafora, (2008): Remittances: Transaction Costs, Determinants, and Informal Flows, Journal of Development Economics, 86: 356-66.

Giuliano, Paola and Marta Ruiz-Arranz (2009): Remittances, financial development and growth, Journal of Development Economics, 90, 1: 144-52.

Grogger, J. and G. Hanson (2011): Income maximization and the selection and sorting of international migrants, Journal of Development Economics, 95, 1: 42-57.

Jimenez-Martin, S., N. Jorgensen, and J.M. Labeaga, (2007): The Volume and Geography of Remittances from the EU, Report to the European Commission, 1-70.

Lueth, E., and M. Ruiz-Arranz (2008): Determinants of Bilateral Remittance Flows, B.E. Journal of Macroeconomics, 8, 1: 1-23.

Martin, P.L. (2003): Managing Labor Migration: Temporary Worker Programs for the 21st Century, ILO Publications, Geneva, September 2003.

Mayda, A. (2010): International migration: A panel data analysis of the determinants of bilateral flows, Journal of Population Economics, 23, 4: 1249-1274.

McDowell, L. (2003): Workers, migrants, aliens or citizens? State constructions and discourses of identity among post-war European labour migrants in Britain, Political Geography, 22: 863-86.

McFadden, D. (1984): Econometric analysis of qualitative response models, in: Z. Griliches and M. Intriligator (eds), Handbook of Econometrics, Volume 2, Amsterdam. Elsevier/North-Holland.

McKenzie, D. and H. Rapoport (2010): Self-selection patterns in Mexico-US migration: the role of migration networks, Review of Economics and Statistics, 92, 4: 811-21. 
Morrison, A.R., M. Schiff, and M. Sjoblom, (2008): The International Migration of Women, World Bank: Palgrave Macmillan.

Niimi, Y., C. Özden and M. Schiff (2010): Remittances and the brain drain: skilled migrants do remit less!, Annales d'Economie et de Statistique, 97-98: 123-142.

Ortega, F. and G. Peri (2009), The Causes and Effects of International Labor Mobility: Evidence from OECD Countries 1980-2005, Working Paper, UC Davis.

Pritchett, L. (2006): Let their people come. Breaking the gridlock on global labor mobility, Washington, DC: Center for Global Development.

Rapoport, H. and F. Docquier (2006): The economics of migrants' remittances, in S.-C. Kolm and J. Mercier Ythier (eds): Handbook of the Economics of Giving, Altruism and Reciprocity, Amsterdam: North Holland, Chapter 17, pp. 1135-98.

Roy, A.D. (1951): Some thoughts on the distribution of earnings, Oxford Economic Papers, 3 (2), 135-46.

Ruhs, M. and P. Martin (2008): Numbers vs. Rights: Trade-Offs and Guest Worker Programs, International Migration Review, 42, 1, 249-65.

Santos Silva, J.M.C. and S. Tenreyro (2006): The log of gravity, Review of Economics and Statistics, 88, 4: 641-658.

Schioupu, I. and N. Siegfried (2006): Determinants of Workers Remittances. Evidence from the European Neighbouring Region, European Central Bank Working Paper Series No 688, October.

Yang, D. (2008): International migration, remittances and household investment: evidence from Philippine migrants' exchange rate shocks, Economic Journal, 118: 591-630.

World Bank (2011): World Bank's Migration and Remittances Factbook 2011. Second Edition. Washington DC. 


\section{Bar-Ilan University \\ Department of Economics \\ WORKING PAPERS}

1-01 The Optimal Size for a Minority

Hillel Rapoport and Avi Weiss, January 2001.

2-01 An Application of a Switching Regimes Regression to the Study of Urban Structure

Gershon Alperovich and Joseph Deutsch, January 2001.

3-01 The Kuznets Curve and the Impact of Various Income Sources on the Link Between Inequality and Development

Joseph Deutsch and Jacques Silber, February 2001.

4-01 International Asset Allocation: A New Perspective

Abraham Lioui and Patrice Poncet, February 2001.

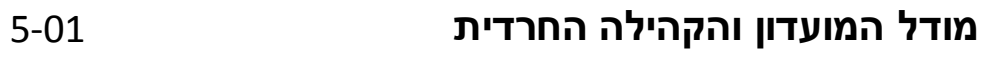

יעקב רוזנברג, פברואר 2001.

6-01 Multi-Generation Model of Immigrant Earnings: Theory and Application Gil S. Epstein and Tikva Lecker, February 2001.

7-01 Shattered Rails, Ruined Credit: Financial Fragility and Railroad Operations in the Great Depression

Daniel A. Schiffman, February 2001.

8-01 Cooperation and Competition in a Duopoly R\&D Market

Damiano Bruno Silipo and Avi Weiss, March 2001.

9-01 A Theory of Immigration Amnesties

Gil S. Epstein and Avi Weiss, April 2001.

10-01 Dynamic Asset Pricing With Non-Redundant Forwards Abraham Lioui and Patrice Poncet, May 2001.

11-01 Macroeconomic and Labor Market Impact of Russian Immigration in Israel Sarit Cohen and Chang-Tai Hsieh, May 2001.

Electronic versions of the papers are available at 
12-01 Network Topology and the Efficiency of Equilibrium Igal Milchtaich, June 2001.

13-01 General Equilibrium Pricing of Trading Strategy Risk Abraham Lioui and Patrice Poncet, July 2001.

14-01 Social Conformity and Child Labor Shirit Katav-Herz, July 2001.

15-01 Determinants of Railroad Capital Structure, 1830-1885 Daniel A. Schiffman, July 2001.

16-01 Political-Legal Institutions and the Railroad Financing Mix, 1885-1929 Daniel A. Schiffman, September 2001.

17-01 Macroeconomic Instability, Migration, and the Option Value of Education Eliakim Katz and Hillel Rapoport, October 2001.

18-01 Property Rights, Theft, and Efficiency: The Biblical Waiver of Fines in the Case of Confessed Theft

Eliakim Katz and Jacob Rosenberg, November 2001.

19-01 Ethnic Discrimination and the Migration of Skilled Labor Frédéric Docquier and Hillel Rapoport, December 2001.

1-02 Can Vocational Education Improve the Wages of Minorities and Disadvantaged Groups? The Case of Israel Shoshana Neuman and Adrian Ziderman, February 2002.

2-02 What Can the Price Gap between Branded and Private Label Products Tell Us about Markups?

Robert Barsky, Mark Bergen, Shantanu Dutta, and Daniel Levy, March 2002.

3-02 Holiday Price Rigidity and Cost of Price Adjustment Daniel Levy, Georg Müller, Shantanu Dutta, and Mark Bergen, March 2002.

4-02 Computation of Completely Mixed Equilibrium Payoffs Igal Milchtaich, March 2002.

5-02 Coordination and Critical Mass in a Network Market - An Experimental Evaluation

Amir Etziony and Avi Weiss, March 2002. 
6-02 Inviting Competition to Achieve Critical Mass

Amir Etziony and Avi Weiss, April 2002.

7-02 Credibility, Pre-Production and Inviting Competition in a Network Market Amir Etziony and Avi Weiss, April 2002.

8-02 Brain Drain and LDCs' Growth: Winners and Losers

Michel Beine, Fréderic Docquier, and Hillel Rapoport, April 2002.

9-02 Heterogeneity in Price Rigidity: Evidence from a Case Study Using MicroLevel Data

Daniel Levy, Shantanu Dutta, and Mark Bergen, April 2002.

10-02 Price Flexibility in Channels of Distribution: Evidence from Scanner Data Shantanu Dutta, Mark Bergen, and Daniel Levy, April 2002.

11-02 Acquired Cooperation in Finite-Horizon Dynamic Games Igal Milchtaich and Avi Weiss, April 2002.

12-02 Cointegration in Frequency Domain Daniel Levy, May 2002.

13-02 Which Voting Rules Elicit Informative Voting? Ruth Ben-Yashar and Igal Milchtaich, May 2002.

14-02 Fertility, Non-Altruism and Economic Growth: Industrialization in the Nineteenth Century

Elise S. Brezis, October 2002.

15-02 Changes in the Recruitment and Education of the Power Elitesin Twentieth Century Western Democracies

Elise S. Brezis and François Crouzet, November 2002.

16-02 On the Typical Spectral Shape of an Economic Variable Daniel Levy and Hashem Dezhbakhsh, December 2002.

17-02 International Evidence on Output Fluctuation and Shock Persistence Daniel Levy and Hashem Dezhbakhsh, December 2002.

1-03 Topological Conditions for Uniqueness of Equilibrium in Networks Igal Milchtaich, March 2003.

2-03 Is the Feldstein-Horioka Puzzle Really a Puzzle? Daniel Levy, June 2003. 
3-03 Growth and Convergence across the US: Evidence from County-Level Data Matthew Higgins, Daniel Levy, and Andrew Young, June 2003.

4-03 Economic Growth and Endogenous Intergenerational Altruism Hillel Rapoport and Jean-Pierre Vidal, June 2003.

5-03 Remittances and Inequality: A Dynamic Migration Model Frédéric Docquier and Hillel Rapoport, June 2003.

6-03 Sigma Convergence Versus Beta Convergence: Evidence from U.S. CountyLevel Data

Andrew T. Young, Matthew J. Higgins, and Daniel Levy, September 2003.

7-03 Managerial and Customer Costs of Price Adjustment: Direct Evidence from Industrial Markets

Mark J. Zbaracki, Mark Ritson, Daniel Levy, Shantanu Dutta, and Mark Bergen, September 2003.

8-03 First and Second Best Voting Rules in Committees

Ruth Ben-Yashar and Igal Milchtaich, October 2003.

9-03 Shattering the Myth of Costless Price Changes: Emerging Perspectives on Dynamic Pricing

Mark Bergen, Shantanu Dutta, Daniel Levy, Mark Ritson, and Mark J. Zbaracki, November 2003.

1-04 Heterogeneity in Convergence Rates and Income Determination across U.S. States: Evidence from County-Level Data

Andrew T. Young, Matthew J. Higgins, and Daniel Levy, January 2004.

2-04 “The Real Thing:" Nominal Price Rigidity of the Nickel Coke, 1886-1959 Daniel Levy and Andrew T. Young, February 2004.

3-04 Network Effects and the Dynamics of Migration and Inequality: Theory and Evidence from Mexico

David Mckenzie and Hillel Rapoport, March 2004.

4-04 Migration Selectivity and the Evolution of Spatial Inequality Ravi Kanbur and Hillel Rapoport, March 2004.

5-04 Many Types of Human Capital and Many Roles in U.S. Growth: Evidence from County-Level Educational Attainment Data

Andrew T. Young, Daniel Levy and Matthew J. Higgins, March 2004. 
6-04 When Little Things Mean a Lot: On the Inefficiency of Item Pricing Laws Mark Bergen, Daniel Levy, Sourav Ray, Paul H. Rubin and Benjamin Zeliger, May 2004.

7-04 Comparative Statics of Altruism and Spite Igal Milchtaich, June 2004.

8-04 Asymmetric Price Adjustment in the Small: An Implication of Rational Inattention

Daniel Levy, Haipeng (Allan) Chen, Sourav Ray and Mark Bergen, July 2004.

1-05 Private Label Price Rigidity during Holiday Periods

Georg Müller, Mark Bergen, Shantanu Dutta and Daniel Levy, March 2005.

2-05 Asymmetric Wholesale Pricing: Theory and Evidence

Sourav Ray, Haipeng (Allan) Chen, Mark Bergen and Daniel Levy, March 2005.

3-05 Beyond the Cost of Price Adjustment: Investments in Pricing Capital Mark Zbaracki, Mark Bergen, Shantanu Dutta, Daniel Levy and Mark Ritson, May 2005.

4-05 Explicit Evidence on an Implicit Contract Andrew T. Young and Daniel Levy, June 2005.

5-05 Popular Perceptions and Political Economy in the Contrived World of Harry Potter

Avichai Snir and Daniel Levy, September 2005.

6-05 Growth and Convergence across the US: Evidence from County-Level Data (revised version)

Matthew J. Higgins, Daniel Levy, and Andrew T. Young, September 2005.

1-06 Sigma Convergence Versus Beta Convergence: Evidence from U.S. CountyLevel Data (revised version)

Andrew T. Young, Matthew J. Higgins, and Daniel Levy, June 2006.

2-06 Price Rigidity and Flexibility: Recent Theoretical Developments Daniel Levy, September 2006.

3-06 The Anatomy of a Price Cut: Discovering Organizational Sources of the Costs of Price Adjustment

Mark J. Zbaracki, Mark Bergen, and Daniel Levy, September 2006. 
4-06 Holiday Non-Price Rigidity and Cost of Adjustment

Georg Müller, Mark Bergen, Shantanu Dutta, and Daniel Levy.

September 2006.

2008-01 Weighted Congestion Games With Separable Preferences

Igal Milchtaich, October 2008.

2008-02 Federal, State, and Local Governments: Evaluating their Separate Roles in US Growth

Andrew T. Young, Daniel Levy, and Matthew J. Higgins, December 2008.

2008-03 Political Profit and the Invention of Modern Currency

Dror Goldberg, December 2008.

2008-04 Static Stability in Games

Igal Milchtaich, December 2008.

2008-05 Comparative Statics of Altruism and Spite

Igal Milchtaich, December 2008.

2008-06 Abortion and Human Capital Accumulation: A Contribution to the Understanding of the Gender Gap in Education

Leonid V. Azarnert, December 2008.

2008-07 Involuntary Integration in Public Education, Fertility and Human

Capital

Leonid V. Azarnert, December 2008.

2009-01 Inter-Ethnic Redistribution and Human Capital Investments

Leonid V. Azarnert, January 2009.

2009-02 Group Specific Public Goods, Orchestration of Interest Groups and Free Riding

Gil S. Epstein and Yosef Mealem, January 2009.

2009-03 Holiday Price Rigidity and Cost of Price Adjustment

Daniel Levy, Haipeng Chen, Georg Müller, Shantanu Dutta, and Mark Bergen, February 2009.

2009-04 Legal Tender

Dror Goldberg, April 2009.

2009-05 The Tax-Foundation Theory of Fiat Money

Dror Goldberg, April 2009. 
2009-06 The Inventions and Diffusion of Hyperinflatable Currency

Dror Goldberg, April 2009.

2009-07 The Rise and Fall of America's First Bank

Dror Goldberg, April 2009.

2009-08 Judicial Independence and the Validity of Controverted Elections

Raphaël Franck, April 2009.

2009-09 A General Index of Inherent Risk

Adi Schnytzer and Sara Westreich, April 2009.

2009-10 Measuring the Extent of Inside Trading in Horse Betting Markets

Adi Schnytzer, Martien Lamers and Vasiliki Makropoulou, April 2009.

2009-11 The Impact of Insider Trading on Forecasting in a Bookmakers' Horse Betting Market

Adi Schnytzer, Martien Lamers and Vasiliki Makropoulou, April 2009.

2009-12 Foreign Aid, Fertility and Population Growth: Evidence from Africa Leonid V. Azarnert, April 2009.

2009-13 A Reevaluation of the Role of Family in Immigrants' Labor Market Activity: Evidence from a Comparison of Single and Married Immigrants Sarit Cohen-Goldner, Chemi Gotlibovski and Nava Kahana, May 2009.

2009-14 The Efficient and Fair Approval of "Multiple-Cost-Single-Benefit" Projects Under Unilateral Information

Nava Kahanaa, Yosef Mealem and Shmuel Nitzan, May 2009.

2009-15 Après nous le Déluge: Fertility and the Intensity of Struggle against Immigration

Leonid V. Azarnert, June 2009.

2009-16 Is Specialization Desirable in Committee Decision Making?

Ruth Ben-Yashar, Winston T.H. Koh and Shmuel Nitzan, June 2009.

2009-17 Framing-Based Choice: A Model of Decision-Making Under Risk

Kobi Kriesler and Shmuel Nitzan, June 2009.

2009-18 Demystifying the 'Metric Approach to Social Compromise with the Unanimity Criterion'

Shmuel Nitzan, June 2009. 
2009-19 On the Robustness of Brain Gain Estimates

Michel Beine, Frédéric Docquier and Hillel Rapoport, July 2009.

2009-20 Wage Mobility in Israel: The Effect of Sectoral Concentration

Ana Rute Cardoso, Shoshana Neuman and Adrian Ziderman, July 2009.

2009-21 Intermittent Employment: Work Histories of Israeli Men and Women, 1983-1995

Shoshana Neuman and Adrian Ziderman, July 2009.

2009-22 National Aggregates and Individual Disaffiliation: An International Study

Pablo Brañas-Garza, Teresa García-Muñoz and Shoshana Neuman, July 2009.

2009-23 The Big Carrot: High-Stakes Incentives Revisited

Pablo Brañas-Garza, Teresa García-Muñoz and Shoshana Neuman, July 2009.

2009-24 The Why, When and How of Immigration Amnesties

Gil S. Epstein and Avi Weiss, September 2009.

2009-25 Documenting the Brain Drain of "la Crème de la Crème»: Three Case-Studies on International Migration at the Upper Tail of the Education Distribution

Frédéric Docquier and Hillel Rapoport, October 2009.

2009-26 Remittances and the Brain Drain Revisited: The Microdata Show That More Educated Migrants Remit More

Albert Bollard, David McKenzie, Melanie Morten and Hillel Rapoport, October 2009.

2009-27 Implementability of Correlated and Communication Equilibrium

Outcomes in Incomplete Information Games

Igal Milchtaich, November 2009.

2010-01 The Ultimatum Game and Expected Utility Maximization - In View of Attachment Theory

Shaul Almakias and Avi Weiss, January 2010.

2010-02 A Model of Fault Allocation in Contract Law - Moving From Dividing Liability to Dividing Costs

Osnat Jacobi and Avi Weiss, January 2010. 
2010-03 Coordination and Critical Mass in a Network Market: An Experimental Investigation

Bradley J. Ruffle, Avi Weiss and Amir Etziony, February 2010.

2010-04 Immigration, fertility and human capital: A model of economic decline of the West

Leonid V. Azarnert, April 2010.

2010-05 Is Skilled Immigration Always Good for Growth in the Receiving Economy?

Leonid V. Azarnert, April 2010.

2010-06 The Effect of Limited Search Ability on the Quality of Competitive Rent-Seeking Clubs

Shmuel Nitzan and Kobi Kriesler, April 2010.

2010-07 Condorcet vs. Borda in Light of a Dual Majoritarian Approach

Eyal Baharad and Shmuel Nitzan, April 2010.

2010-08 Prize Sharing in Collective Contests

Shmuel Nitzan and Kaoru Ueda, April 2010.

2010-09 Network Topology and Equilibrium Existence in Weighted Network Congestion Games

Igal Milchtaich, May 2010.

2010-10 The Evolution of Secularization: Cultural Transmission, Religion and Fertility Theory, Simulations and Evidence

Ronen Bar-El, Teresa García-Muñoz, Shoshana Neuman and Yossef Tobol, June 2010.

2010-11 The Economics of Collective Brands

Arthur Fishman, Israel Finkelstein, Avi Simhon and Nira Yacouel, July 2010.

2010-12 Interactions Between Local and Migrant Workers at the Workplace

Gil S. Epstein and Yosef Mealem, August 2010.

2010-13 A Political Economy of the Immigrant Assimilation: Internal Dynamics

Gil S. Epstein and Ira N. Gang, August 2010.

2010-14 Attitudes to Risk and Roulette

Adi Schnytzer and Sara Westreich, August 2010. 
2010-15 Life Satisfaction and Income Inequality

Paolo Verme, August 2010.

2010-16 The Poverty Reduction Capacity of Private and Public Transfers in Transition

Paolo Verme, August 2010.

2010-17 Migration and Culture

Gil S. Epstein and Ira N. Gang, August 2010.

2010-18 Political Culture and Discrimination in Contests

Gil S. Epstein, Yosef Mealem and Shmuel Nitzan, October 2010.

2010-19 Governing Interest Groups and Rent Dissipation

Gil S. Epstein and Yosef Mealem, November 2010.

2010-20 Beyond Condorcet: Optimal Aggregation Rules Using Voting Records

Eyal Baharad, Jacob Goldberger, Moshe Koppel and Shmuel Nitzan, December 2010.

2010-21 Price Points and Price Rigidity

Daniel Levy, Dongwon Lee, Haipeng (Allan) Chen, Robert J. Kauffman and Mark Bergen, December 2010.

2010-22 Price Setting and Price Adjustment in Some European Union

Countries: Introduction to the Special Issue

Daniel Levy and Frank Smets, December 2010.

2011-01 Business as Usual: A Consumer Search Theory of Sticky Prices and Asymmetric Price Adjustment

Luís Cabral and Arthur Fishman, January 2011.

2011-02 Emigration and democracy

Frédéric Docquier, Elisabetta Lodigiani, Hillel Rapoport and Maurice Schiff, January 2011.

2011-03 Shrinking Goods and Sticky Prices: Theory and Evidence

Avichai Snir and Daniel Levy, March 2011.

2011-04 Search Costs and Risky Investment in Quality

Arthur Fishman and Nadav Levy, March 2011. 
2011-05 To What Extent do Investors in a Financial Market Anchor Their Judgments? Evidence from the Hong Kong Horserace Betting Market Johnnie E.V. Johnson, Shuang Liu and Adi Schnytzer, March 2011.

2011-06 Attitudes to Risk and Roulette

Adi Schnytzer and Sara Westreich, March 2011.

2011-07 False Consciousness in Financial Markets: Or is it in Ivory Towers? Adi Schnytzer and Sara Westreich, March 2011.

2011-08 Herding in Imperfect Betting Markets with Inside Traders

Adi Schnytzer and Avichai Snir, March 2011.

2011-09 Painful Regret and Elation at the Track

Adi Schnytzer and Barbara Luppi, March 2011.

2011-10 The Regression Tournament: A Novel Approach to Prediction Model Assessment

Adi Schnytzer and Janez Šušteršič, March 2011.

2011-11 Shorting the Bear: A Test of Anecdotal Evidence of Insider Trading in Early Stages of the Sub-Prime Market Crisis

Les Coleman and Adi Schnytzer, March 2011.

2011-12 SP Betting as a Self-Enforcing Implicit Cartel

Adi Schnytzer and Avichai Snir, March 2011.

2011-13 Testing for Home Team and Favorite Biases in the Australian Rules Football Fixed Odds and Point Spread Betting Markets

Adi Schnytzer and Guy Weinberg, March 2011.

2011-14 The Impact of Insider Trading on Forecasting in a Bookmakers' Horse Betting Market

Adi Schnytzer, Martien Lamers and Vasiliki Makropoulou, March 2011.

2011-15 The Prediction Market for the Australian Football League

Adi Schnytzer, March 2011.

2011-16 Information and Attitudes to Risk at the Track

Adi Schnytzer and Sara Westreich, March 2011.

2011-17 Explicit Evidence on an Implicit Contract

Andrew T. Young and Daniel Levy, March 2011. 
2011-18 Globalization, Brain Drain and Development

Frédéric Docquier and Hillel Rapoport, March 2011.

2011-19 The Impact of Worker Effort on Public Sentiment Towards Temporary Migrants

Gil S. Epstein and Alessandra Venturini, April 2011.

2011-20 Animal Modeling of Earthquakes and Prediction Markets

Adi Schnytzer and Yisrael Schnytzer, May 2011.

2011-21 A Field Study of Social Learning

Arthur Fishman and Uri Gneezy, May 2011.

2011-22 MD Dialog on: Optimum Savings and Optimal Growth: the CassMalinvaud-Koopmans Nexus

Stephen E. Spear and Warren Young, May 2011.

2011-23 Privilege-Seeking Activities in Organizational Politics and Its Effect on More Productive Employees

Gil S. Epstein and Bruce C. Herniter, August 2011.

2011-24 Integrated Public Education, Fertility and Human Capital

Leonid V. Azarnert, August 2011.

2011-25 Male vs. Female Guest-Worker Migration: Does it Matter for Fertility in the Source Country?

Leonid V. Azarnert, August 2011.

2011-26 Tradable Immigration Quotas

Jesús Fernández-Huertas Moraga and Hillel Rapoport, September 2011.

2011-27 Remittances, Migrants" Education and Immigration Policy: Theory and Evidence from Bilateral Data

Frédéric Docquier, Hillel Rapoport and Sara Salomone, October 2011. 